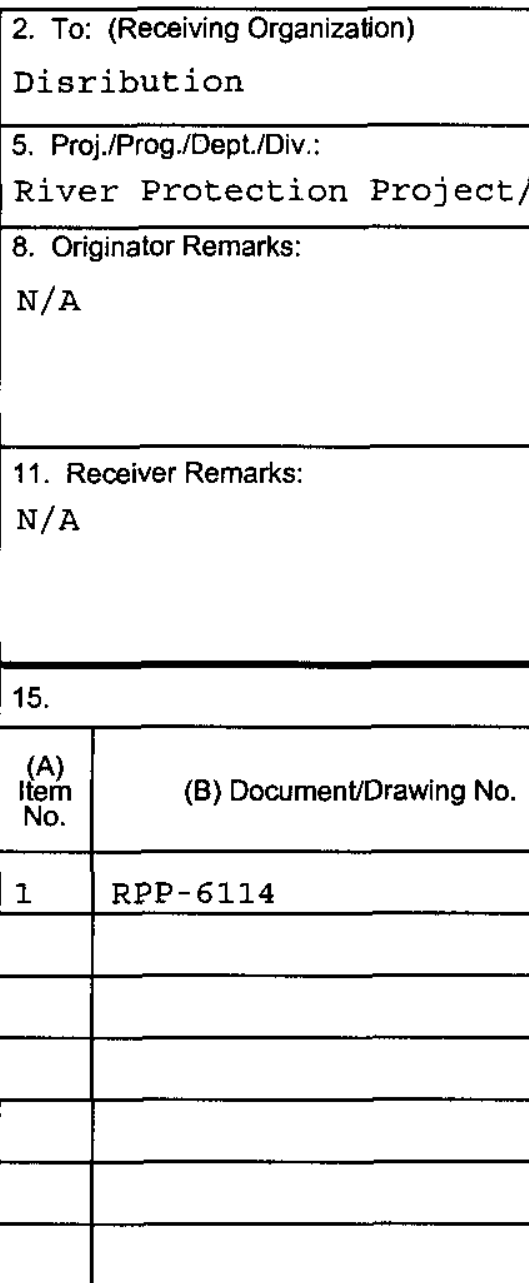

16.

3. From: (Originating Organization)
Project Controls
$\begin{aligned} & \text { 6. Design Authority/Design Agent/Cog. Engr.: } \\ & \text { JW Bosley, } 373-5177\end{aligned}$

JW Bosley, 373-5177
4. Related EDT No.:
N/A
7. Purchase Order No.:
$\mathrm{N} / \mathrm{A}$
9. Equip./Component No.:
$\mathrm{N} / \mathrm{A}$
10. System/BIdg./Facility:
N/A
12. Major Assm. Dwg. No.:
$\mathrm{N} / \mathrm{A}$

13. Permit/Permit Application No.:

$\mathrm{N} / \mathrm{A}$

14. Required Response Date:

$\mathrm{N} / \mathrm{A}$

\section{DATA TRANSMITTED}

$\begin{gathered}\text { (C) Sheet } \\ \text { No. }\end{gathered}$
(D) Rov.

(F)

(G)

A

\begin{tabular}{|c|c|c|c|}
\hline (F) & $(G)$ & $\overline{(ㄴ ㅣ ㅅ ㅣ ~}$ & 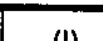 \\
\hline 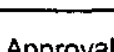 & Reras & Origi & Receiv \\
\hline
\end{tabular}

Desig- for Trans- nator er

nator mittal Dispo- Dispo-

$\mathrm{N} / \mathrm{A}$

$0 \quad$ Human Resources Staffing

Plan for the Tank Farm

Contractor

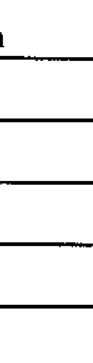

KEY

\begin{tabular}{|c|l|}
\hline Approval Designator $(F)$ & \\
\hline E, S, Q, D OR N/A & 1. Approval \\
(See WHC-CM-3-5, & 2. Release \\
Sec. 12.7) & 3. Information \\
\hline
\end{tabular}

17.

Reason for Transmittal (G)

4. Review

5. Post-Review

6. Dist. (Receipt Acknow. Required)

SIGNATURE/DISTRIBUTION

(See Approval Designator for required signatures)

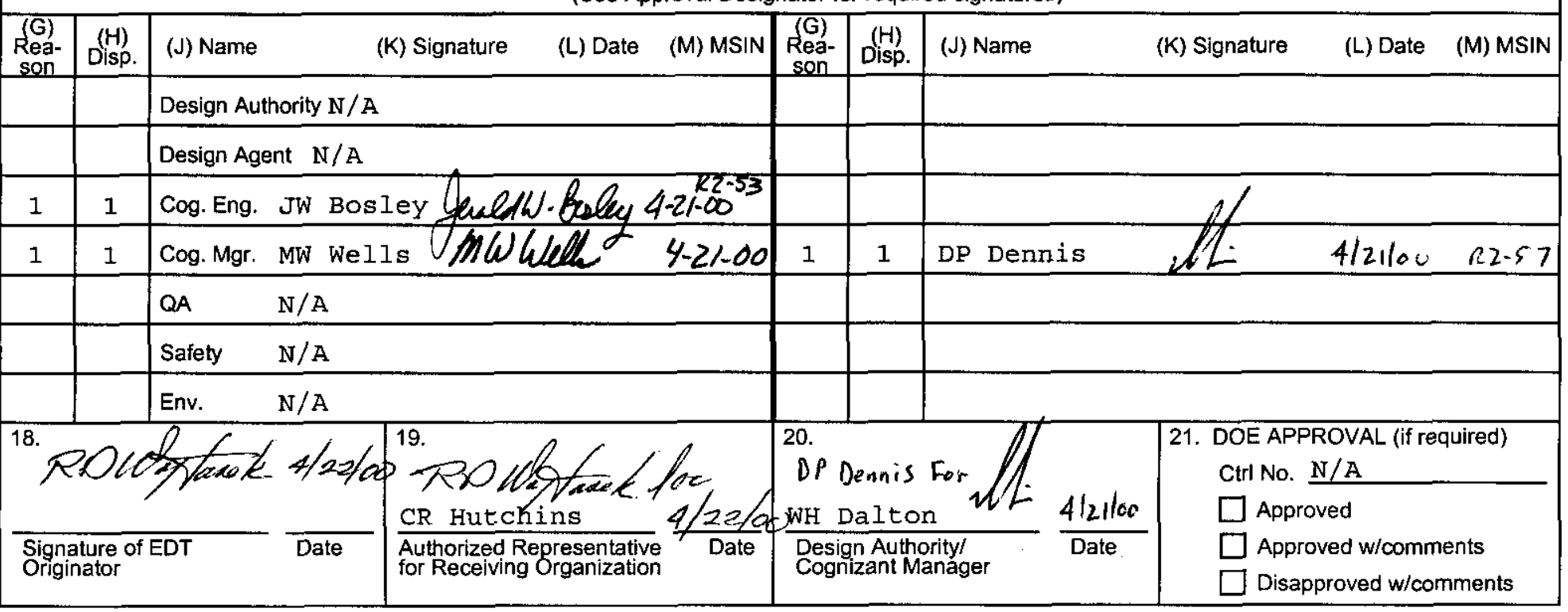




\title{
Human Resources Staffing Plan for the Tank Farm Contractor
}

\author{
J.W. Bosley and D.P. Dennis \\ CH2M HILL Hanford Group, Inc. \\ Richland, WA 99352 \\ U.S. Department of Energy Contract DE-AC06-99RL14047
EDT/ECN: $629526 \quad$ UC: 2030
Cost Center: $71110 \quad$ Charge Code: 108521/AA30
B\&R Code: EW3130010 Total Pages: 49

Key Words: staffing, Skills, Recruitment, Resources

\begin{abstract}
The Human Resources staffing Plan quantified the equivalent staffing needs required for the Tank Farm Contractor (TFC) and its subcontractors to execute the readiness to proceed baseline between FY 2000-2008. The TFC staffing needs were assessed along with the staffings needs of Fluor Hanford and the privatization contractor. The plan then addressed the staffing needs and recruitment strategies required to execute the baseline.
\end{abstract}

TRADEMARK DISCLAIMER. Reference herein to any specific commercial product, process, or service by trade name, trademark, manufacturer, or otherwise, does not necessarily constitute or imply its endorsement, recommendation, or favoring by the United States Government or any agency thereof or its contractors or subcontractors.

Printed in the United States of America. To obtain copies of this document, contact: Document Control Services, P.O. Box 950, Mailstop H6-08, Richland WA 99352, Phone (509) 372-2420; Fax (509) 376-4989.
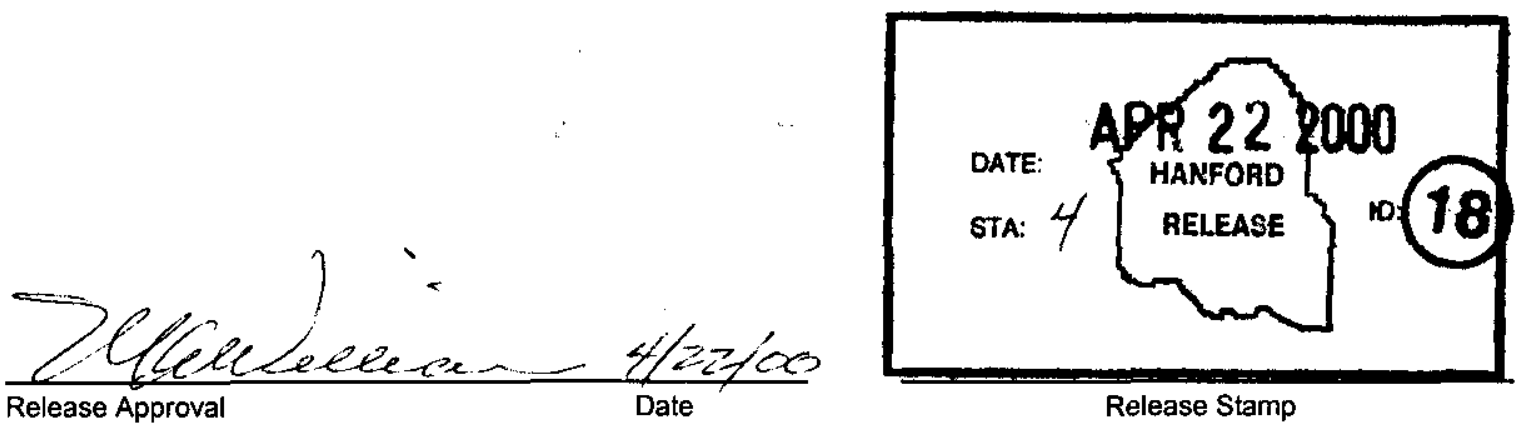

\section{Approved For Public Release}


RPP-6114 REV 0

This page intentionally left blank. 
Document Title: Human Resources Staffing Plan for the Tank Farm Contractor

Approved by:

M.P.tutularo

C.R. Hutchins, Vice President

Planning and Integration

CH2M HILL Hanford Group, Inc.

Approved by:

$$
4 / 21 / 00
$$

Date

W.H. Dalton, Director

$4 / 21 / 00$

Date

Human Resources

CH2M HILL Hanford Group, Inc. 
RPP-6114 REV 0

This page intentionally left blank. 


\section{EXECUTIVE SUMMARY}

This staffing plan demonstrates that CH2M HILL Hanford Group, Inc. (CHG), can successfully recruit and hire the personnel required to execute the Readiness-to-Proceed (RPT) declaration. The staffing plan addresses fiscal years 2000 through 2008, which coincide with the start-up of hot operations of the vitrification facilities. Staffing needs were determined and strategies developed to ensure that mission objectives can be met with the competing demands from other Site activities.

To determine staffing needs, CHG developed a detailed resource-loaded Primavera Project Planner ${ }^{\mathrm{TM}}$ life-cycle baseline. Staffing needs were determined from this baseline. CHG's staffing needs were combined with those of Fluor Hanford, Inc. (FH), for the Plutonium Finishing Plant, Spent Nuclear Fuel, River Corridor, and Waste Management projects and those of the Privatization Contractor for its construction, operations, and maintenance activities. FH project staff requirements are identified in Section 2.3, and the Privatization Contractor's staff requirements are identified in Section 2.4. This staffing plan was developed by CHG to determine its staffing needs. Data provided by FH and the Privatization Contractor are included in this plan for information purposes only. The combined staffing profile for $\mathrm{CHG}, \mathrm{FH}$, and the Privatization Contractor appears in Table 2-10.

CHG's baseline staffing profile noted above is summarized by Common Occupational Category System (COCS) codes as identified in Attachment A. This staffing profile is based on an estimated mix of CHG and subcontractor staff to execute the RTP baseline. As these positions are required, CHG will determine the applicability of subcontracting to fulfill the needs, particularly when the need is of limited duration.

CHG identified four non-project areas in which skill needs will experience exceptional growth (increases of $10 \%$ or more or an increase of greater than twelve full-time positions in excess of normal attrition, the larger of these overlapping two fiscal years) and will be in demand by competing companies above those levels estimated to be available in the local market when needed. The four areas identified by the application of this threshold are identified in Figure 4-1. The four areas are crafts, engineers, operators, and health physics technicians. Specific recruiting strategies have been developed for each skill area to ensure that appropriate skills can be acquired to meet mission objectives as discussed in Sections 4.0 and 5.0.

Specific recruitment strategies developed to address future staff requirements include on-the-job training programs, targeted recruitment, subcontracting, use of architect/engineer firms, and leveraging construction firms to meet staffing demands. Based on the evaluation completed for this staffing plan, $\mathrm{CHG}$ is confident that it can recruit the staff required to execute Phase $1 \mathrm{~B}$ of Privatization. The recruitment strategies identified are flexible enough to accommodate changes in staff mix and to support changes in the RTP baseline. 


\section{RPP-6114 REV 0}

When construction staffing needs of $\mathrm{CHG}$ are combined with Privatization Contractor's staffing needs, approximately 4,000 construction-related positions are required at its peak in fiscal year 2003 to support feed delivery/storage construction projects. These staffing needs are identified in Table 2-9; the construction/subcontract recruitment process is discussed in Section 5.0. Construction-related staffing needs can be provided through architect/engineer vendors, local union halls, construction resources from Umatilla Army Depot out-year downsizing, and reduced Washington state construction resulting from passage of Initiative 695. 


\section{RPP-6114 REV 0}

\section{CONTENTS}

$1.0 \quad$ BACKGROUND AND PURPOSE ………….................................................... 1-1

2.0 STAFFING NEEDS DISCUSSION ………....................................................... 2-1

2.1 CH2M HILL HANFORD GROUP, INC., NON-PROJECT STAFF................. 2-1

2.2 FEED DELIVERY/STORAGE CONSTRUCTION PROJECTS AND OPERATIONS SUPPORT TO PROJECTS.................................................. 2-2

2.3 FLUOR HANFORD, INC., PROJECT STAFFING NEEDS ……..................... 2-5

2.4 VITRIFICATION CONTRACTOR OPERATIONS, MAINTENANCE, AND CONSTRUCTION ......................................................................... 2-5

2.5 OVERALL SUMMARY OF STAFFING NEEDS ……………........................ 2-7

2.5.1 Non-Project Staffing Needs ............................................................... 2-7

2.5.2 Construction Staffing Needs ............................................................ 2-7

2.5.3 Combined Non-Project and Construction Staffing Needs ........................ 2-7

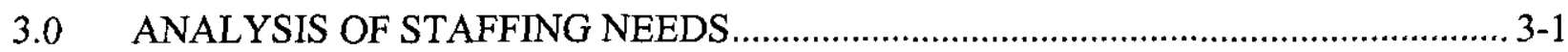

$3.1 \quad$ NON-PROJECT STAFFING ANALYSIS ……............................................ 3-1

3.2 CONSTRUCTION STAFFING ANALYSIS ……........................................... 3-2

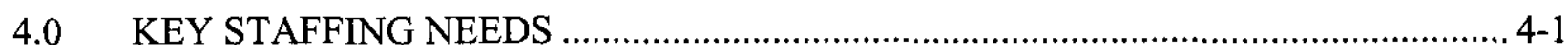

5.0 STRATEGY TO MEET HIRING NEEDS.......................................................... 5-1

5.1 TAILORED RECRUITMENT METHODS FOR IDENTIFIED SKILL

AREAS

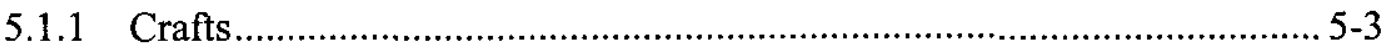

5.1.2 Engineers.................................................................................. 5-4

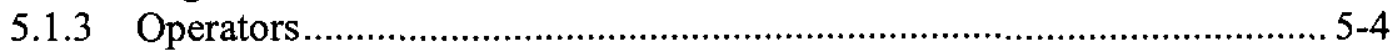

5.1.4 Health Physics Technicians ............................................................ 5-5

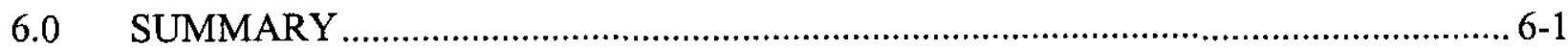

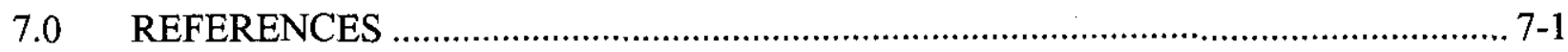

\section{ATTACHMENTS}

A CH2M HILL HANFORD GROUP, INC., NON-PROFIT STAFFING PROFILE SUMMARY

B STAFFING NEEDS FOR FEED DELIVERY/STORAGE CONSTRUCTION PROJECTS 
RPP-6114 REV 0

FIGURES

Figure 1-1. CH2M HILL Hanford Group, Inc., Document Hierarchy.

Figure 4-1. CH2M HILL Hanford Group, Inc., Skill Areas Requiring Recruitment Strategies.

\section{TABLES}

Table 2-1. CH2M HILL Hanford Group, Inc., Non-Project Staffing Profile Summary. ......... 2-2

Table 2-2. Feed Delivery/Storage Line Item Funding (Dollars in Thousands) ......................2-3

Table 2-3. CH2M HILL Hanford Group, Inc., Feed Delivery/Storage Construction Staff Requirements.

Table 2-4. CH2M HILL Hanford Group, Inc., Operations Staffing Needs to Support Feed Delivery/Storage Construction Projects.

Table 2-5. Fluor Hanford, Inc., Projects - Staffing Profile Summary (Plutonium Finishing Plant, Spent Nuclear Fuel, River Corridor, and Waste Management).

Table 2-6. Privatization Contractor's Staffing Profile Summary - Operations and Maintenance $2-6$

Table 2-7. Privatization Contractor's Staffing Profile Summary - Construction....... 2-6

Table 2-8. CH2M HILL Hanford Group, Inc; Fluor Hanford, Inc.; and Privatization Contractor Staffing Profile Summary - Non-Project.

Table 2-9. CH2M HILL Hanford Group, Inc.; Fluor Hanford, Inc.; and Privatization Contractor Staffing Profile Summary - Construction.

Table 2-10. CH2M HILL Hanford Group, Inc.; Fluor Hanford, Inc.; and Privatization Contractor Staffing Profile Summary. $2-8$

Table 4-1. CH2M HILL Hanford Group, Inc., Non-Project Staffing Profile Summary for Crafts, Engineers, Operators, and Health Physics Technicians Requiring Specific Recruitment Strategies.

Table 5-1. Recruitment Process. .......................................................................... 5-2

Table 5-2. Construction/Subcontract Recruitment Process. .......................................... 5-3 


\section{RPP-6114 REV 0}

\section{TERMS}

$\begin{array}{ll}\text { A/E } & \text { architect/engineer } \\ \text { BHI } & \text { Bechtel Hanford Inc. } \\ \text { CHG } & \text { CH2M HILL Hanford Group, Inc. } \\ \text { COCS } & \text { Common Occupational Category System } \\ \text { DOE } & \text { U.S. Department of Energy } \\ \text { DST } & \text { double-shell tank } \\ \text { FFS } & \text { Fluor Federal Services } \\ \text { FH } & \text { Fluor Hanford, Inc. } \\ \text { FY } & \text { fiscal year } \\ \text { HAMTC } & \text { Hanford Atomic Metal Trades Council } \\ \text { HPT } & \text { health physics technician } \\ \text { HR } & \text { Human Resources } \\ \text { ORP } & \text { Office of River Protection } \\ \text { P3 } & \text { Primavera Project Planner } \\ \text { RPP } & \text { River Protection Project } \\ \text { RTP } & \text { Readiness to Proceed } \\ \text { SST } & \text { single-shell tank } \\ \text { Tri-Party Agreement } & \text { Hanford Federal Facility Agreement and Consent Order }\end{array}$


RPP-6114 REV 0

This page intentionally left blank. 


\section{RPP-6114 REV 0}

\subsection{BACKGROUND AND PURPOSE}

In December 1991, the Secretary of Energy directed that the Tank Waste Remediation System be established to plan and implement the disposal of tank waste at the Hanford Site. A strategy was developed and negotiated, and the revised Hanford Federal Facility Agreement and Consent Order (Tri-Party Agreement) (Ecology et al. 1996) was signed. The strategy envisioned the following activities:

- Retrieval of waste from both single-shell tanks (SST) and double-shell tanks (DST)

- Separation of waste into high-activity and low-activity fractions

- Immobilization of the low-activity fraction in glass or other suitable form that would reduce volume and meet long-term disposal requirements

- Vitrification of the high-activity fraction for disposal in a national repository for high-level waste.

In 1994, concern about balancing the Federal budget became a national issue. The U.S. Department of Energy (DOE) believed that a new approach was needed for funding and managing the construction and operation of the multi-billion dollar facilities needed for waste treatment and immobilization. After considering past experience and input from the commercial industry, the DOE decided on a privatization approach to accomplish tank waste treatment at the Hanford Site. Privatization is a two-phase fixed-unit-price contracting method for providing waste treatment and immobilization services. The DOE intends to award a contract under which the contractor will design, build, and operate waste immobilization facilities. The Office of River Protection (ORP) was established to manage the Hanford Site's tank waste retrieval, treatment, and disposal, which includes the privatization contract.

The purpose of this human resources (HR) staffing plan is to quantify the equivalent staffing needs required for the Tank Farm Contractor, CH2M HILL Hanford Group, Inc. (CHG), and its subcontractors to execute the Readiness-to-Proceed (RTP) baseline between FY 2000 and FY 2008, based on planned operation of the vitrification facilities. The plan also provides a recruitment strategy for securing specific skills (such as crafts, engineers, operators, and health physics technicians [HPT]), the need for which will grow and who will be in demand by competing companies. The staffing plan is a supporting document within the CHG document hierarchy as identified in Figure 1-1. 


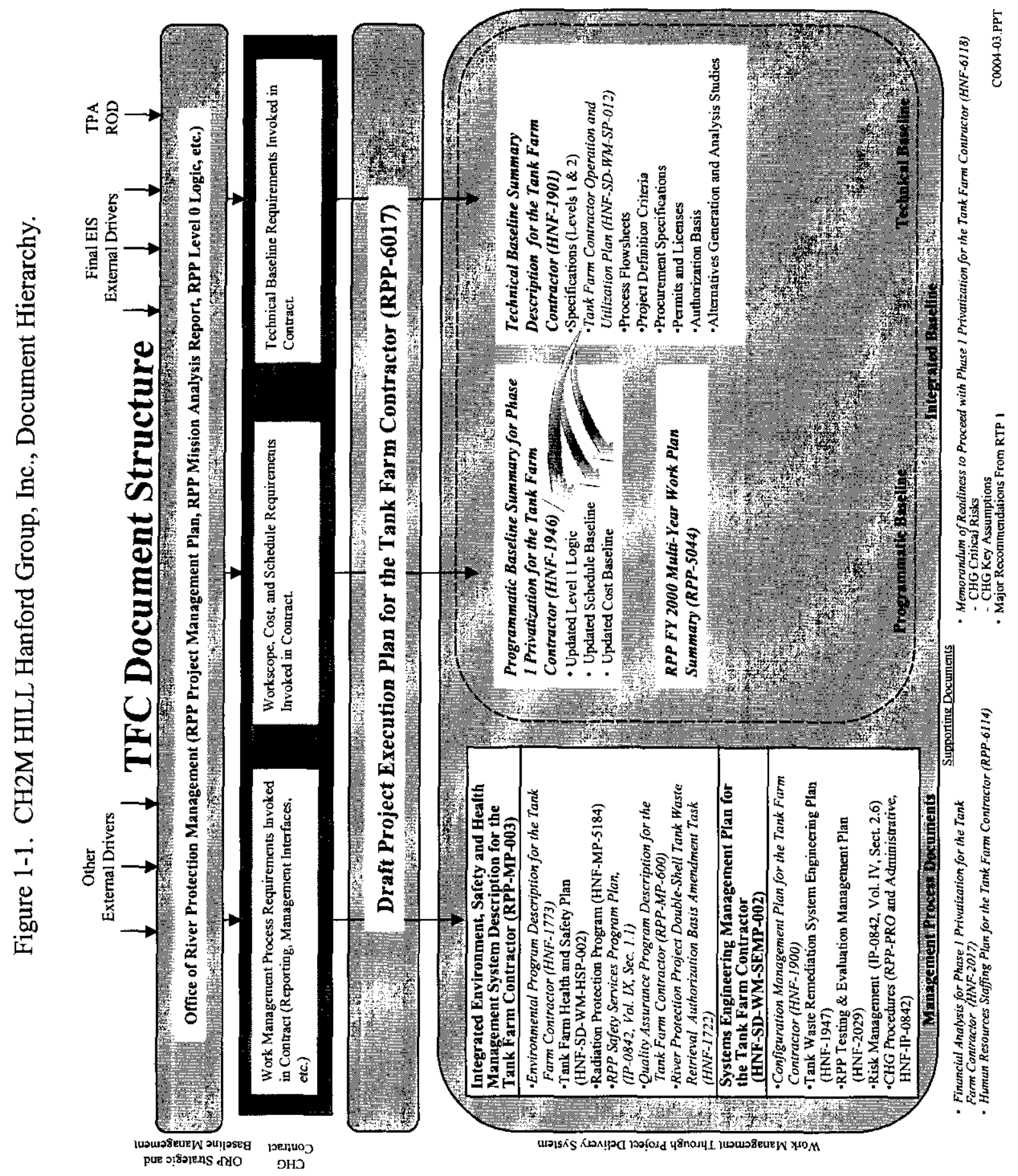


RPP-6114 REV 0

1-3 
RPP-6114 REV 0

\subsection{STAFFING NEEDS DISCUSSION}

\subsection{CH2M HILL HANFORD GROUP, INC., NON-PROJECT STAFF}

CHG non-project staff needs are the positions identified in the RTP Primavera Project Planner ${ }^{\mathrm{TM}}$ (P3) resource files by Common Occupational Category System (COCS) categories, an estimated need for subcontractor support, and $\mathrm{CHG}$ operator, craft, and operating engineer support to the Privatization Contractor. CHG and subcontractor non-project staffing needs are identified in Attachment A. To determine the staffing profile for subcontractor support, $\mathrm{CHG}$ converted contract dollars within the baseline to equivalent full-time positions and an estimated skills mix. The subcontractor support was assumed to be of a skills mix similar to that of current CHG staff, excluding bargaining unit employees.

CHG also reviewed the variables associated with labor agreement effects, attrition, and service demands on Fluor Hanford, Inc. (FH), to determine whether further adjustments to baseline staff needs were required.

CHG initially reviewed non-project staff requirements for the effects on labor agreements of the transfer or "bumping" of operators throughout the Hanford Site. Operator reductions planned by $\mathrm{FH}$ in FY 2004 are expected to result in the bumping of $25 \%$ of CHG's operators from their current positions by operators with greater seniority than $\mathrm{CHG}$ operators. Therefore, the FY 2004 baseline data were adjusted to address the effect on CHG of having to train 31 nuclear waste process operators until they are qualified to perform River Protection Project (RPP) activities. This adjustment was necessary to determine the total number of nuclear waste process operators required to execute baseline plans. The adjustment is identified in Attachment A. CHG also evaluated the potential effects on maintenance crafts and HPTs of bumping by seniority. CHG determined that its maintenance crafts and HPTs generally have greater seniority than FH's maintenance crafts and HPTs and would not be affected. Based on this evaluation, adjustments to the baseline were not required for maintenance crafts and HPTs. CHG then evaluated staff requirements to determine whether the average employee attrition rates would affect the recruitment plan threshold levels in COCS categories. CHG determined that the effects of attrition would be minimal, and therefore these categories would not require specific recruiting strategies.

CHG evaluated staff positions that are in the baseline for direct-funded personnel whose services will be purchased from $\mathrm{FH}$ and the level of service $\mathrm{CHG}$ expects to continue purchasing from Hanford Site service pools. Based on this evaluation, CHG's expectation is that the level of services purchased from $\mathrm{FH}$ will remain fairly constant through FY 2008, as indicated in Attachment A. Therefore, no specific strategies were developed to recruit personnel associated with this work scope.

The total CHG non-project staffing profile identified in Table 2-1 is based on the above evaluation. 


\section{RPP-6114 REV 0}

The CHG baseline for FY 2005 shows an increase of 270 staff among craft, operators, and operating engineers for the Privatization Contractor. The data are included in the staffing plan to highlight the need for these resources at the Hanford Site and to acknowledge the $\$ 26,376,000$ included in the CHG baseline for labor costs associated with training these individuals. However, the hiring and training for these positions is not the contractual responsibility of CHG. CHG has requested that ORP resolve the issue of who is responsible for hiring and training the staff for these positions through the Integrated Process and Product Development/Interface Control Document process.

Table 2-1. CH2M HILL Hanford Group, Inc., Non-Project Staffing Profile Summary.

\begin{tabular}{|c|c|c|c|c|c|c|c|c|c|}
\hline 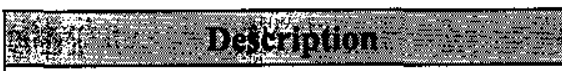 & 10900 & 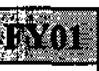 & $\mathrm{FYO2}^{2}$ & Fro3 & EY04 & 1805 & 2006 & 100 & 17ng: \\
\hline $\begin{array}{l}\text { CHG non-project staff } \\
\text { (including FH and NHC support) }\end{array}$ & 1,634 & 1,599 & 1,660 & 1,559 & 1,402 & 1,215 & 1,177 & 1,282 & 1,4 \\
\hline ntractor & 466 & 458 & 496 & 453 & 413 & 479 & 493 & 580 & 4 \\
\hline $\begin{array}{l}\text { Operator, craft, } \\
\text { support for the } \mathrm{P}\end{array}$ & 0 & 0 & 0 & 0 & 0 & 270 & 0 & 0 & \\
\hline Totals & 2,100 & 2,057 & 2,156 & 1,012 & 1,815 & 1,964 & 1,670 & 1,862 & 1,818 \\
\hline
\end{tabular}

1. FY 2005 data include 270 positions that are in the $\mathrm{CHG}$ baseline for Privatization Contractor ( 108 crafts, 108 operators, and 54 operating engineers). The issue of who is responsible for hiring and one year of training requires resolution by the Office of River Protection.

2. Staffing needs for FY 2004 and beyond may be underestimated; not all Privatization Phase 2 activities have identified staffing needs. Out-year decline in planned activities may make operators available for Phase 2 activities.

3. Staffing profile based on a planned mix of $\mathrm{CHG}$ and subcontractor staff. As these positions are required, CHG will determine the appropriateness of subcontracting to fulfill the needs.

$$
\begin{aligned}
& \text { CHG }=\text { CH2M HILL Hanford Group, Inc. } \\
& \text { FY }=\text { fiscal year. } \\
& \text { NHC }=\text { Numatec Hanford Company. }
\end{aligned}
$$

\subsection{FEED DELIVERY/STORAGE CONSTRUCTION PROJECTS AND OPERATIONS SUPPORT TO PROJECTS}

CHG feed delivery/storage construction projects will provide the necessary infrastructure and systems needed to support delivery of waste to the Privatization Contractor. Staffing needs for feed delivery/storage construction projects include staff to perform project management, system design, and construction activities. Staffing requirements for these projects are not identified in the baseline as COCS codes. Therefore, dollars in the baseline for these activities were converted to equivalent skill areas based on historical knowledge of project requirements. This section will quantify the equivalent staff. The active line item budgets, for these projects, needed to meet waste feed delivery objectives are listed in Table 2-2. 


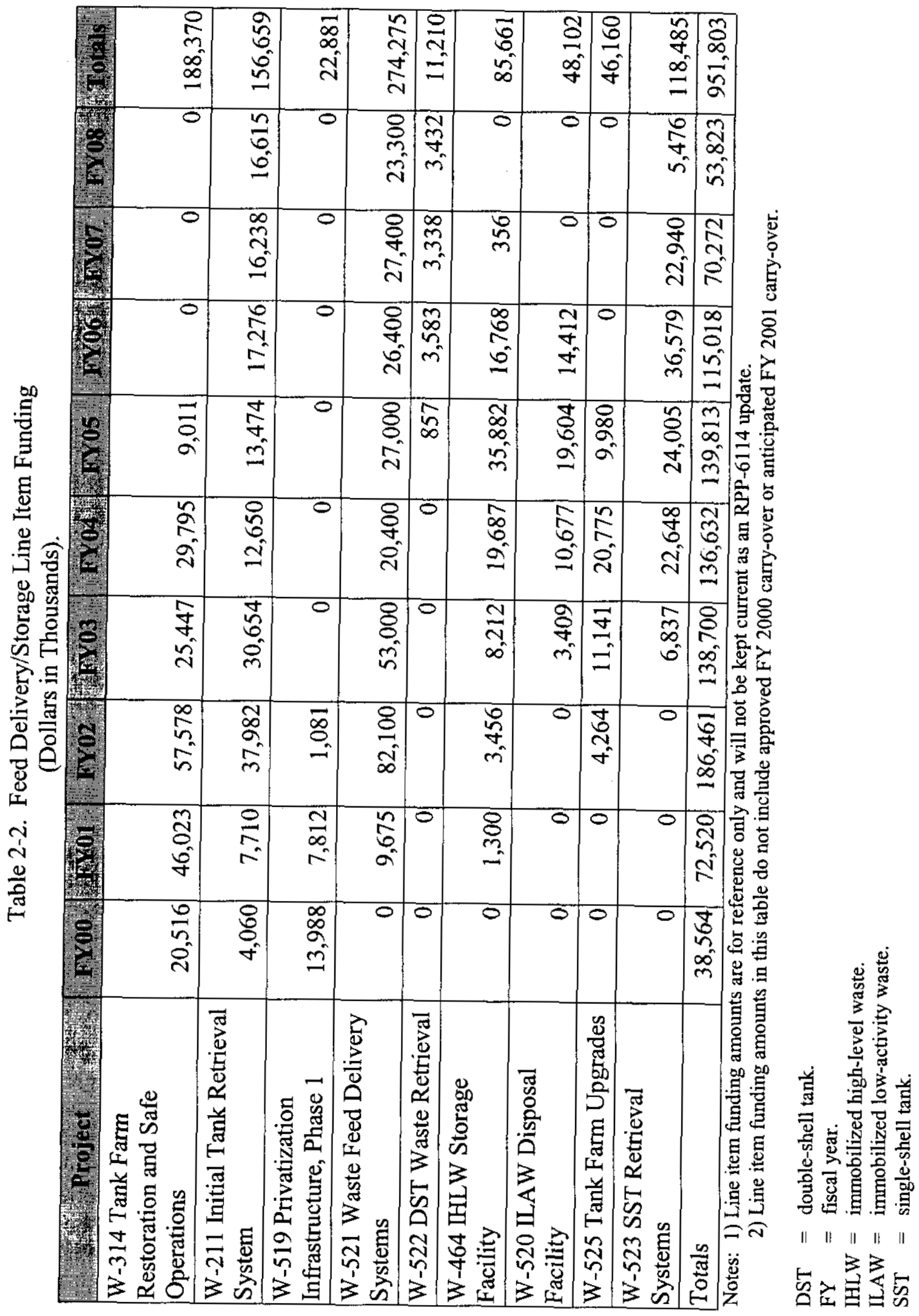




\section{RPP-6114 REV 0}

Over the next nine years (FY 2000 through FY 2008), line item construction projects will account for approximately $\$ 950$ million of business volume, which will result in increased staffing needs. Of the $\$ 950$ million, $\$ 125$ million is contingency and $\$ 150$ million is for procurement, neither of which convert to equivalent staff, since these are funds for major equipment purchases or costs not assumed to drive requirements for additional staff. The balance of $\$ 675$ million was converted to equivalent staff requirements for project management, $\mathrm{A} / \mathrm{E}$ design and construction activities for construction projects, and $\mathrm{CHG}$ operations staff for feed delivery storage, as shown in Tables 2-3 and 2-4. Detailed COCS information for Table 2-3 appears in Attachment B. Procurement activities have been addressed in the Project Delivery Acquisition and Contracting Plan for the Tank Farm Contractor, RPP-6113 (Mercado 2000).

Table 2-3. CH2M HILL Hanford Group, Inc., Feed Delivery/Storage Construction Staff Requirements.

\begin{tabular}{|c|c|c|c|c|c|c|c|c|c|}
\hline 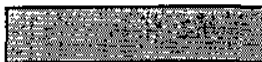 & $=80$ & FY01 & rYo2 & FY03 & FYo4 & Fros & 2060 & $1 \times 1 \times 07$ & EY \\
\hline & 98 & 288 & 613 & 421 & 464 & 408 & 278 & 171 & \\
\hline
\end{tabular}

$\mathrm{FY}=$ fiscal year.

Table 2-4. CH2M HILL Hanford Group, Inc., Operations Staffing Needs to Support Feed Delivery/Storage Construction Projects.

\begin{tabular}{|c|c|c|c|c|c|c|c|c|c|c|}
\hline cocs & eogstive & 1500 & EY01 & FY2 & PY03 & Yrou & $1 \mathrm{10} 05$ & 1206 & FY07. & IV08 \\
\hline $\mathrm{C} 000$ & Crafts & 1 & 1 & 1 & 1 & 1 & 1 & 1 & 1 & 1 \\
\hline $\mathrm{C} 020$ & Electricians & 1 & 1 & 1 & 1 & 1 & 1 & 1 & 1 & 1 \\
\hline $\mathrm{CO80}$ & Plumbers and pipefitters & 1 & 1 & 1 & 1 & 1 & 1 & 1 & 1 & 1 \\
\hline $\mathrm{C} 090$ & Structural and metal workers & 2 & 2 & 2 & 2 & 2 & 2 & 2 & 2 & 2 \\
\hline E100 & Plant engineers & 3 & 4 & 4 & 7 & 8 & 8 & 7 & 5 . & 7 \\
\hline E110 & Quality control engineers & 3 & 4 & 4 & 7 & 8 & 8 & 7 & 5 & 7 \\
\hline $\mathrm{E} 120$ & Safety engineers & 3 & 4 & 4 & 7 & 8 & 8 & 7 & 5 & 7 \\
\hline E130 & Other engineers & 2 & 3 & 3 & 6 & 7 & 7 & 6 & 4 & 6 \\
\hline M010 & First-line supervisors & 4 & 5 & 5 & 8 & 9 & 9 & 8 & 6 & 8 \\
\hline $\mathrm{P} 070$ & Planner/scheduler/estimators & 7 & 10 & 10 & 19 & 22 & 22 & 19 & 13 & 19 \\
\hline $\mathrm{P} 090$ & Industrial hygienists & 1 & 1 & 1 & 1 & 1 & 1 & 1. & 1 & 1 \\
\hline P170 & Other professionals & 2 & 3 & 3 & 6 & 7 & 7 & 6 & 4 & 6 \\
\hline $\mathrm{R} 050$ & Nuclear waste process operators & 8 & 10 & 10 & 16 & 18 & 18 & 16 & 8 & 16 \\
\hline T050 & Health physics technicians & 20 & 28 & 28 & 52 & 60 & 60 & 52 & 36 & 52 \\
\hline T060 & Industrial health/safety technicians & 2 & 3 & 3 & 6 & 7 & 7 & 6 & 4 & 6 \\
\hline Totals & & 59 & 79 & 79 & 139 & 159 & 159 & 139 & 95 & 139 \\
\hline
\end{tabular}




\subsection{FLUOR HANFORD, INC., PROJECT STAFFING NEEDS}

FH provided CHG with staffing profiles for four major projects (Plutonium Finishing Plant, Spent Nuclear Fuel, River Corridor, and Waste Management) that are required above the support to CHG. Based on its data, FH has determined that it will be shutting down some projects at the same time CHG and the Privatization Contractor will be adding staff for Phase 1B. In FY 2004, FH will be reducing the number of nuclear operator, HPT, craft, and exempt positions. These personnel could be used to fill a majority of the positions expected by the Privatization Contractor in FY 2005 (see Section 3.0). The FH staffing profile appears in Table 2-5.

Table 2-5. Fluor Hanford, Inc., Projects - Staffing Profile Summary

(Plutonium Finishing Plant, Spent Nuclear Fuel, River Corridor, and Waste Management).

\begin{tabular}{|c|c|c|c|c|c|c|}
\hline Description & 800 & 1)0 & Nive & 1903 & 10.7. & nos \\
\hline Exempt & 1,262 & 1,244 & 1,178 & 1,133 & 970 & 866 \\
\hline Non-exempt & 137 & 132 & 131 & 125 & 111 & 98 \\
\hline Nuclear operators & 319 & 412 & 418 & 412 & 297 & 283 \\
\hline Non-nuclear operators & 34 & 35 & 40 & 38 & 32 & 28 \\
\hline Health physics technicians & 170 & 210 & 221 & 218 & 158 & 158 \\
\hline Crafts & 242 & 258 & 256 & 234 & 189 & 192 \\
\hline Totals & 2,164 & 2,292 & 2,244 & 2,160 & 1,757 & 1,625 \\
\hline
\end{tabular}

Note: FH staffing requirements do not include $\mathrm{FH}$ indirect staffing needs.

FH = Fluor Hanford, Inc.

$F Y=$ fiscal year.

\subsection{VITRIFICATION CONTRACTOR OPERATIONS, MAINTENANCE, AND CONSTRUCTION}

The Privatization Contractor provided CHG with staffing profiles for operations, maintenance, and construction activities to support tank waste vitrification. The Privatization Contractor's need for operators and HPTs in the FY 2003 through FY 2005 period coincides with FH's planned staffing reductions in the same skill areas (discussed in Section 3.0). The Privatization Contractor's operations, maintenance, and construction staffing requirements are shown in Tables 2-6 and 2-7. 
Table 2-6. Privatization Contractor's Staffing Profile Summary Operations and Maintenance.

\begin{tabular}{|c|c|c|c|c|c|c|c|c|c|}
\hline 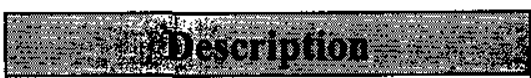 & SOM & 80 & 19 & $1 \times 1$ & Pho & Was & $\mathrm{Tot}$ & Sor & sisos \\
\hline Cold commissioning N-M & 0 & 10 & 28 & 90 & 115 & 117 & 105 & 15 & 0 \\
\hline Cold commissioning craft & 0 & 3 & 16 & 73 & 209 & 194 & 37 & 0 & 0 \\
\hline Operations N-M & 0 & 37 & 66 & 61 & 170 & 268 & 265 & 265 & 265 \\
\hline Nuclear chemical operator & 0 & 0 & 0 & 9 & 30 & 101 & 146 & 151 & 0 \\
\hline Stationary operating engineer & 0 & 0 & 0 & 5 & 11 & 30 & 49 & 54 & 54 \\
\hline Janitor & 0 & 0 & 0 & 0 & 0 & 0 & 0 & 0 & 0 \\
\hline Instrument - lead & 0 & 0 & 0 & 0 & 5 & 39 & 49 & 49 & 49 \\
\hline Instrument craftsman & 0 & 0 & 0 & 0 & 0 & 0 & 20 & 20 & 20 \\
\hline Electrician & 0 & 0 & 0 & 0 & 5 & 20 & 26 & 26 & 26 \\
\hline Plumber/pipefitter & 0 & 0 & 0 & 0 & 5 & 44 & 70 & 70 & 70 \\
\hline Health physics technician & 0 & 0 & 0 & 0 & 0 & 6 & 25 & 36 & 36 \\
\hline Chemical technician & 0 & 0 & 0 & 1 & 1 & 4 & 6 & 6 & 6 \\
\hline Totals & 0 & 50 & 110 & 239 & 551 & 823 & 798 & 692 & 526 \\
\hline
\end{tabular}

Table 2-7. Privatization Contractor's Staffing Profile Summary - Construction.

\begin{tabular}{|c|c|c|c|c|c|c|c|c|c|}
\hline 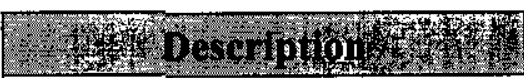 & 19000 & 40 & 00 & 100 & $\mathrm{rroy}$ & 205 & A. 606 & 1807 & In:87: \\
\hline IJV other project office & 221 & 377 & 392 & 332 & 287 & 239 & 151 & 115 & 0 \\
\hline SPC other project office & 84 & 106 & 120 & 149 & 195 & 234 & 266 & 268 & 252 \\
\hline Design engineering & 620 & 870 & 720 & 465 & 260 & 210 & 120 & 0 & 0 \\
\hline Construction, N-M & 7 & 228 & 371 & 410 & 319 & 107 & 0 & 0 & 0 \\
\hline Construction, craft & 0 & 882 & 1,455 & 2,121 & 907 & 141 & 0 & 0 & 0 \\
\hline Totals & 932 & 2,463 & 3,058 & 3,477 & 1,968 & 931 & 537 & 383 & 252 \\
\hline $\begin{array}{l}\mathrm{FY}=\text { fiscal year. } \\
\mathrm{IJV}=\text { Integrated Joint Venture } \\
\mathrm{N}-\mathrm{M}=\text { non-manual } \\
\mathrm{SPC}=\text { Special Purpose Company }\end{array}$ & & & & & & & & & \\
\hline
\end{tabular}

Detailed recruitment strategies for the Privatization Contractor are under development. 


\subsection{OVERALL SUMMARY OF STAFFING NEEDS}

\subsubsection{Non-Project Staffing Needs}

The combined non-project staffing needs for CHG, FH, and the Privatization Contractor are shown in Table 2-8. These data are analyzed in Section 3.0.

Table 2-8. CH2M HILL Hanford Group, Inc; Fluor Hanford, Inc.; and Privatization Contractor Staffing Profile Summary - Non-Project.

\begin{tabular}{|c|c|c|c|c|c|c|c|c|c|}
\hline 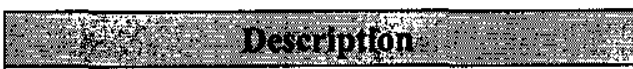 & 5. & smyen & 302 & 200 & mo4 & ryos & 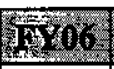 & anog & 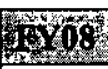 \\
\hline $\begin{array}{l}\text { CHG non-project staff - including FH and } \\
\text { NHC support to RPP }\end{array}$ & 1,634 & 1,599 & 1,660 & 1,559 & 1,402 & 1,215 & 1,177 & 1,282 & 1,405 \\
\hline CHG subcontractor support & 466 & 458 & 496 & 453 & 413 & 479 & 493 & 580 & 413 \\
\hline FH projects staff & 2,164 & 2,292 & 2,244 & 2,160 & 1,757 & 1,625 & 1,625 & 1,625 & 1,625 \\
\hline $\begin{array}{l}\text { Privatization Contractor operations and } \\
\text { maintenance staff }\end{array}$ & 0 & 50 & 110 & 239 & 551 & 823 & 798 & 692 & 526 \\
\hline $\begin{array}{l}\text { Operator, craft, and operating engineer } \\
\text { support for the Privatization Contractor }\end{array}$ & 0 & 0 & 0 & 0 & 0 & 270 & 0 & 0 & 0 \\
\hline Totals & 4,246 & 4,399 & 4,510 & 4,411 & 4,123 & 4,412 & 4,093 & 4,179 & 3,969 \\
\hline
\end{tabular}

1. Staffing needs for FY 2004 and beyond may be underestimated; not all Privatization Phase 2 activities have identified staffing needs. Out-year decline in planned activities may make operators available for Phase 2 activities.

2. FH staffing needs for FY 2006 through FY 2008 were not available. CHG assumed that FH staffing needs for FY 2006 through FY 2008 would be at same level as FY 2005 staffing needs.

3. Staffing profile based on a planned mix of $\mathrm{CHG}$ and subcontractor staff. As these positions are required, CHG will determine the appropriateness of subcontracting to fulfill the needs.

CHG $=$ CH2M HILL Hanford Group, Inc.

FH = Fluor Hanford, Inc.

$\mathrm{FY} \quad=$ fiscal year.

RPP = River Protection Project.

$\mathrm{NHC}=$ Numatec Hanford Company.

\subsubsection{Construction Staffing Needs}

The combined feed delivery/storage construction staffing needs for $\mathrm{CHG}, \mathrm{FH}$, and the Privatization Contractor are shown in Table 2-9. These data are analyzed in Section 3.0.

\subsubsection{Combined Non-Project and Construction Staffing Needs}

The combined non-project and feed delivery/storage construction staffing needs for $\mathrm{CHG}, \mathrm{FH}$, and the Privatization Contractor are shown in Table 2-10. 


\section{RPP-6114 REV 0}

Table 2-9. CH2M HILL Hanford Group, Inc.; Fluor Hanford, Inc.; and Privatization Contractor Staffing Profile Summary - Construction.

\begin{tabular}{|c|c|c|c|c|c|c|c|c|c|}
\hline 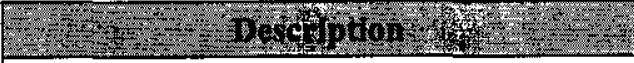 & 180 & 190 & not & 1019 & negen & 1905: & 3.006 & 7in & S180 \\
\hline $\begin{array}{l}\text { CHG operations staff for feed } \\
\text { delivery/storage construction projects }\end{array}$ & 59 & 79 & 79 & 139 & 159 & 159 & 139 & 95 & 139 \\
\hline Feed delivery/storage construction staff & 98 & 288 & 613 & 421 & 464 & 408 & 278 & 171 & 135 \\
\hline Privatization Contractor construction staff & 932 & 2,463 & 3,058 & 3,477 & 1,968 & 931 & 537 & 383 & 252 \\
\hline Totals & 1,089 & 2,830 & 3,750 & 4,037 & 2,591 & 1,498 & 954 & 649 & 526 \\
\hline
\end{tabular}

Table 2-10. CH2M HILL Hanford Group, Inc.; Fluor Hanford, Inc.; and Privatization Contractor Staffing Profile Summary.

\begin{tabular}{|c|c|c|c|c|c|c|c|c|c|}
\hline 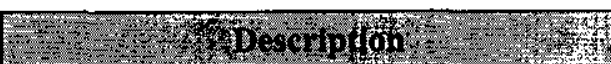 & सOLO & Froi & $\mathrm{FOO}$ & 2003 & Foy & Fys & No6 & IY07 & 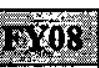 \\
\hline $\begin{array}{l}\text { CHG non-project staff - including FH and } \\
\text { NHC support to RPP }\end{array}$ & 1,634 & 1,599 & 1,660 & 1,559 & 1,402 & 1,215 & 1,177 & 1,282 & 1,405 \\
\hline CHG subcontractor $\mathrm{s}$ & 466 & 458 & 496 & 453 & 413 & 479 & 493 & 580 & 413 \\
\hline $\begin{array}{l}\text { CHG f } \\
\text { constru }\end{array}$ & 98 & 288 & 613 & 421 & 464 & 408 & 278 & 171 & 135 \\
\hline $\begin{array}{l}\text { CHG operations sta } \\
\text { delivery/storage cor }\end{array}$ & 59 & 79 & 79 & 139 & 159 & 159 & 139 & 95 & 139 \\
\hline CHG Subtotal & 2,257 & 2,424 & 2,848 & 2,572 & 2,438 & 2,261 & 2,087 & 2,128 & 2,092 \\
\hline FH projects staff & 2,164 & 2,292 & 2,244 & 2,160 & 1,757 & 1,625 & 1,625 & 1,625 & 1,625 \\
\hline $\begin{array}{l}\text { Operator, craft, and } \\
\text { support for the Priva }\end{array}$ & 0 & 0 & 0 & 0 & 0 & 270 & 0 & 0 & \\
\hline $\begin{array}{l}\text { Privatization Contractor operations and } \\
\text { maintenance staff }\end{array}$ & 0 & 50 & 110 & 239 & 551 & 823 & 798 & 692 & 526 \\
\hline Privatization Contractor construction staff & 932 & 2,463 & 3,058 & 3,477 & 1,968 & 931 & 537 & 383 & 252 \\
\hline Totals & 5,353 & 7,229 & 8,260 & 8,448 & 6,714 & 5,910 & 5,047 & 4,828 & 4,495 \\
\hline
\end{tabular}

1. Staffing needs for FY 2004 and beyond may be underestimated; not all Privatization Phase 2 activities have identified staffing needs. Out-year decline in planned activities may make operators available for Phase 2 activities.

2. FH staffing needs for FY 2006 through FY 2008 were not available. CHG assumed that FH staffing needs for FY 2006 through FY 2008 would be at same level as FY 2005 staffing needs.

3. The staffing profile is based on a planned mix of CHG and subcontractor staff. As these positions are required, CHG will determine the appropriateness of subcontracting to fulfill the needs.
$\mathrm{A} / \mathrm{E}=$ architect/engineer.
$\mathrm{FH} \quad=$ Fluor Hanford, Inc.
$\mathrm{FY} \quad=$ fiscal year.
CHG = CH2M HILL Hanford Group, Inc.
$\mathrm{RPP}=$ River Protection Project.
NHC = Numatec Hanford Company. 
RPP-6114 REV 0

\subsection{ANALYSIS OF STAFFING NEEDS}

\subsection{NON-PROJECT STAFFING ANALYSIS}

Once total baseline staff requirements were developed, a threshold level was applied to target recruitment plans for specific skill need areas with exceptional growth (increases of $10 \%$ or more, or an increase of greater than twelve full-time positions in excess of normal attrition, the larger of these overlapping two fiscal years). COCS increases below these levels are considered routine and will be managed as part of the current $\mathrm{CHG}$ recruiting process.

Non-project staffing needs within CHG will remain fairly constant through FY 2003, then gradually decline through FY 2008. Near-term increases (above assumed threshold) are for 21 HPTs in FY 2001, and an additional 25 HPTs in FY 2002, as outlined in Section 4.0. Attachment A identifies specific COCS requirements for all categories and quantifies the FY 2001 and FY 2002 growth in HPT staffing needs. CHG has the HR staff available to recruit and hire the individuals for these positions.

There is also an increase in staff requirements in FY 2005 of 108 crafts, 108 operators, and 54 operating engineers that are in the CHG baseline for the Privatization Contractor. The data are included in the staffing plan to highlight the need for these resources at the Hanford Site to acknowledge the $\$ 26,376,000$ included in the CHG baseline for labor costs associated with training these individuals. However, the hiring and training of the individuals for these positions is not the contractual responsibility of CHG. CHG has requested that ORP resolve the issue of who is responsible for hiring and training the staff for these positions through the Integrated Process and Product Development/Interface Control Document process.

CHG will incur additional training-related costs for operator transfers and bumping in FY 2004 and additional recruiting costs for planned staffing increases for HPTs in the FY 2001 to FY 2002 period. These costs are not included in the RTP baseline, but will be addressed in the Financial Analysis for Phase 1 Privatization for the Tank Farm Contractor, HNF-2017 (Basche 2000). Recruiting, hiring, and relocation costs for the additional HPT staff in FY 2001 and FY 2002 are estimated to be approximately $\$ 1,250,000$. These costs are in addition to CHG's normal recruiting and hiring budgets. Recruiting and hiring costs for additional crafts, engineers, operators, and HPTs beyond FY 2005, including the staff identified for turnover to the Privatization Contractor, were not calculated. CHG has requested that ORP assist in preparing interface agreements between $\mathrm{CHG}$ and the Privatization Contractor regarding staffing and training responsibilities for the Privatization Contractor-related positions.

In addition, CHG will incur additional costs associated with operator reductions planned by $\mathrm{FH}$ in FY 2004. CHG estimates that 31 nuclear waste process operators will bump CHG operators with a resulting cost increase of approximately $\$ 3,250,000$ to the FY 2004 baseline. These costs are associated with training the new nuclear waste process operators who come from $\mathrm{FH}$ and the requirement to maintain an additional 31 operators in CHG until the new operators are trained and qualified to perform RPP activities. These costs were not included in the RTP baseline but will be addressed in HNF-2017 (Basche 2000). 
CHG has identified key positions in its contract with ORP, in addition to other positions considered key to $\mathrm{CHG}$, and has filled these positions with qualified staff.

Currently, the Privatization Contractor has no Hanford Atomic Metal Trades Council (HAMTC) employees nor a labor contract. CHG has assumed that Privatization Contractor bargaining unit hiring practices would not affect CHG staff. Costs for training and qualifying bargaining unit personnel as they transfer to the various companies would require $\mathrm{CHG}$ to add resources.

\subsection{CONSTRUCTION STAFFING ANALYSIS}

An executability analysis was performed for Feed Delivery/Storage construction projects. Field crosscutting activity (i.e., SST stabilization, transfers, and characterization) constraints were inserted into construction schedules and work activities were logically tied to support transfers to the Privatization Contractor. Resources and scope were "smoothed." Follow-on work in resource validation is planned.

In addition, $\mathrm{CHG}$ is implementing a farm-by-farm construction concept. The executability analysis grouped work activities by farm and developed logic-driven schedules for work optimization. Projects and operations were integrated into these logics. Upcoming actions include the hiring of tank farm construction managers who will coordinate field construction work activities in these areas.

Design activities will multiply four-fold beginning in FY 2001. Expanded A/E pool use is planned for schedule design activities. Design has been identified as a skill that will need to be expanded through use of the $\mathrm{A} / \mathrm{E}$ pool and corporate resources. To prepare for expanded $\mathrm{A} / \mathrm{E}$ pool use, an information session on upcoming (FY 2001 through FY 2002) design work will be held in June 2000. The session will have two main objectives:

- Inform potential vendors of upcoming work and make preparations for upcoming proposals.

- Give CHG feedback on the ability of the current A/E pool to meet its design objectives.

Activities to optimize the design schedule for construction projects, through the executability analysis and the Project Delivery Acquisition and Contracting Plan for the Tank Farm Contractor, RPP-61 13 (Mercado 2000), have been completed. These activities included integrating project design activities for leveling and packaging of similar designs for awards with options for sustained design support from vendors, through establishment of a consistent acquisition process and adoption of a farm-by-farm construction concept that will leverage similar tank designs and reduce duplication.

Field construction activities will expand the need for construction resources currently available through Fluor Federal Services (FFS), CHG's construction vendor. Obtaining these resources, particularly journeyman electricians and pipefitters, will be a top priority worked with construction contractors. Consideration is being given to expanding the construction pool through a competitive bidding process and to using $\mathrm{CHG}$ corporate alliances and resources. 
A preliminary analysis by FFS shows the resource availability in construction crafts. Local union halls, which represent southeastern Washington and northeastern Oregon crafts, show that sufficient number of pipefitters, electricians, and laborers are available to meet the Hanford Site construction staffing requirements. Local union halls have 48 hours to dispatch needed construction craft to a construction vendor. If the union halls are unable to meet required needs, a construction vendor has the right to use other resources. Other resources include recruiting from other union halls, national and local advertisement, and recruitment through corporate subsidiaries. However, FFS has commitments from unions to provide the craft workers needed for the Hanford Site work. The plumbers and steamfitters' union hall has agreed to provide up to 1,200 steamfitters to the Site within 48 hours of notification of the need. In addition, Local 348 of the Laborers' International Union of North America in Pasco, Washington, has approximately 1,200 laborers, with many of them available within 48 hours of being notified of their need at the Hanford Site. Should these resources fail to provide the needed labor, FFS is affiliated with most national unions through corporate agreements and can obtain the required resources.

Other factors will aid the Hanford Site in obtaining necessary construction craft resources. There are no non-Hanford Site construction projects larger than $\$ 100$ million planned in southeastern Washington in the next seven years. Construction by Raytheon Corporation at the Umatilla Army Depot in northeastern Oregon has peaked, and Raytheon will begin downsizing over the next two years. Passage of Initiative 695 has reduced the number of state and municipal construction contracts in Washington state; this reduction has increased resource availability. A number of local union members are working out of the local area. Increased construction activity at the Hanford Site will lure many of them back. By working with local unions, A/E vendors can encourage startup of apprenticeship programs to provide staff for the anticipated demand. Logistical support such as training and support from the Hanford Environmental Health Foundation is being set up for the expected increase in construction-related staff.

Bechtel Hanford, Inc. (BHI), the construction contractor for the vitrification facility, has completed a demographics analysis of the Pacific Northwest that concluded that it will need an apprenticeship program for some crafts; BHI also is expected to bring a number of constructionrelated staff on Site. BNFL Inc. has indicated that BHI has notified the various local unions about staffing requirements and that the unions are beginning to prepare for the work force required for construction. 
RPP-6114 REV 0

This page intentionally left blank. 


\subsection{KEY STAFFING NEEDS}

CHG has identified four skill needs areas that will experience growth beyond the assumed threshold and within which contractors will be competing for staff the four areas identified by the application of this threshold are identified in Figure 4-1. These areas are crafts, engineers, operators, and HPTs. Specific recruiting strategies for each area have been developed, or will be developed, to ensure that appropriate skills can be acquired to meet mission objectives. The staffing profile for these areas is shown in Table 4-1, and specific recruitment strategies are discussed in Section 5.0.

Figure 4-1. CH2M HILL Hanford Group, Inc., Skill Areas Requiring Recruitment Strategies.

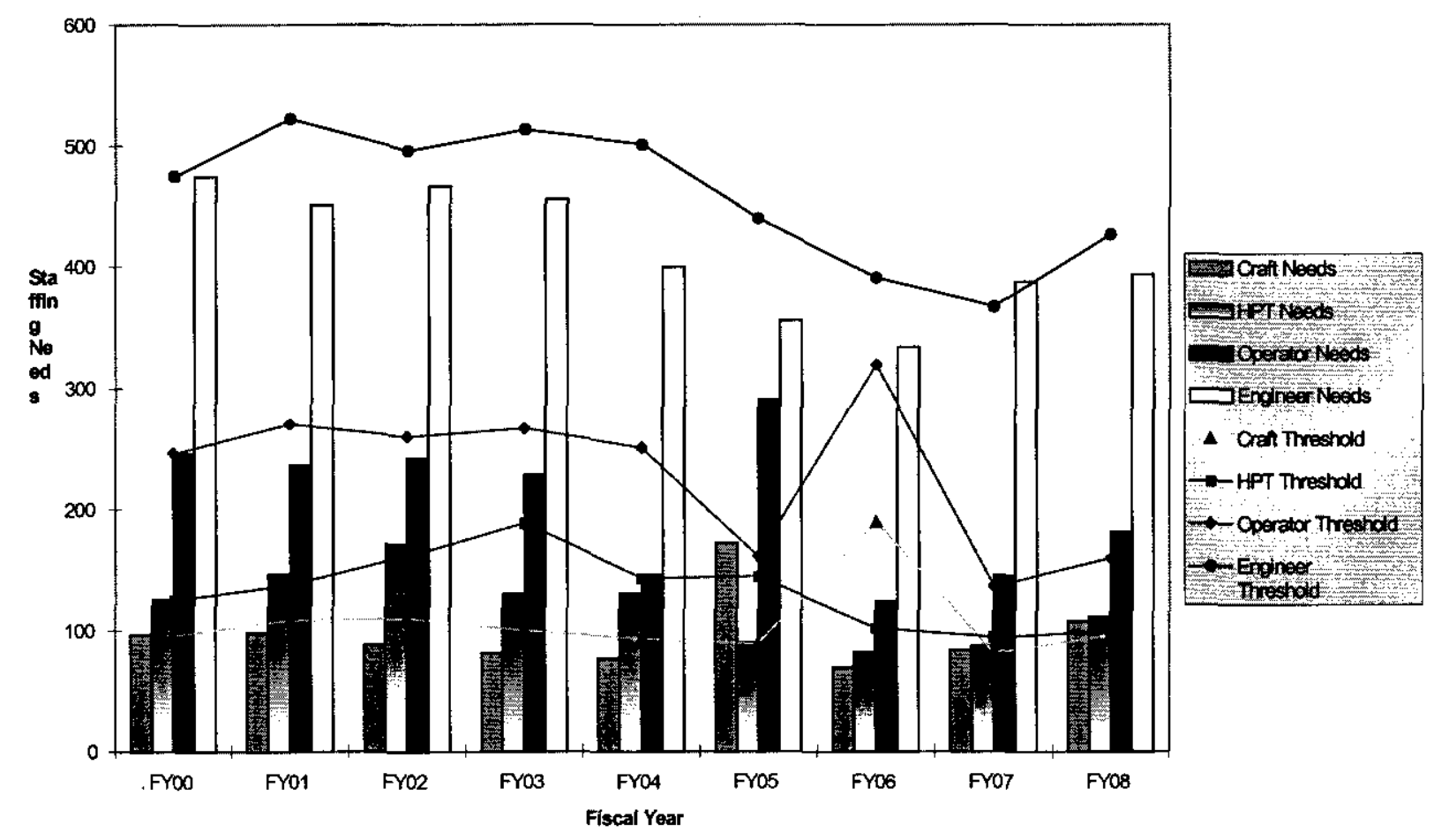




\section{RPP-6114 REV 0}

Table 4-1. CH2M HILL Hanford Group, Inc., Non-Project Staffing Profile Summary for Crafts, Engineers, Operators, and Health Physics Technicians

Requiring Specific Recruitment Strategies.

\begin{tabular}{|c|c|c|c|c|c|c|c|c|c|c|c|c|c|}
\hline 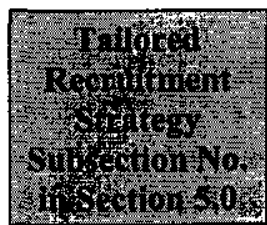 & 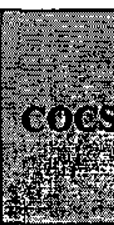 & 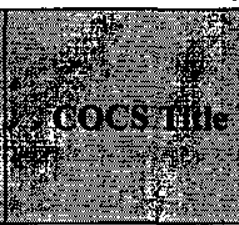 & $4 x$ & Ho & ryot & 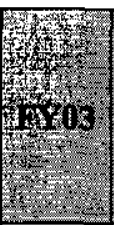 & 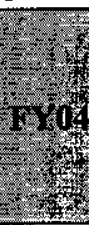 & & $\times 05$ & & 16 & 4 & $\frac{1}{4}$ \\
\hline 5.1 .1 & CXXX & Crafts & 96 & 9 & 88 & 81 & 7 & & 172 & & 69 & 83 & 107 \\
\hline 5.1 .2 & EXXX & Engineers & 475 & 45 & 467 & 456 & 40 & & 356 & & 334 & 388 & 94 \\
\hline 5.1 .3 & $\mathrm{RXXX}$ & Operators & 246 & 23 & 242 & 228 & 14 & & 290 & & 124 & 145 & 81 \\
\hline 1.4 & $\mathrm{~T} 050$ & $\begin{array}{l}\text { Health physics } \\
\text { technicians }\end{array}$ & 125 & 14 & 171 & 130 & 13 & & 90 & & 82 & 87] & \\
\hline
\end{tabular}

1. FY 2005 data include 270 positions that are in the CHG baseline for Privatization Contractor ( 108 crafts, 108 operators, and 54 operating engineers). The issue of who is responsible for hiring and one year of training requires resolution by the Office of River Protection.

2. This table does not include CHG subcontractor staffing needs.

$\mathrm{CHG}=\mathrm{CH} 2 \mathrm{M}$ HILL Hanford Group, Inc.

COCS $=$ Common Occupational Category System.

$\mathrm{FY}=$ fiscal year . 


\section{RPP-6114 REV 0}

\subsection{STRATEGY TO MEET HIRING NEEDS}

CHG recognizes that success in achieving contract objectives depends, in part, on those personnel who perform to the day-to-day requirements of each assigned delivery order. Based on this understanding and on experience in similar efforts, CHG uses a management approach that will attract and retain current employees and facilitate the hiring of new personnel. This fully qualified and experienced staff ensures a smooth, risk-free transition when new employees are hired as well as attainment of ORP's objectives throughout the contract life cycle. The approach is designed to

- Emphasize local hiring

- Minimize hiring of project-oriented staff into $\mathrm{CHG}$ by drawing on the skills resident in the subcontractors available locally to $\mathrm{CHG}$

- Provide flexibility to respond to changing workloads by implementing a cross-training program tailored to long-term service-level delivery orders

- Provide a rapid-response team surge capability from sources outside the core Hanford Site employee base

- Quickly provide qualified replacements for departing employees.

CHG emphasizes a planned, controlled approach to staffing and staff increases. CH2M HILL has been successful in this approach and expects to repeat its success at the Hanford Site to attract and retain talented, dedicated technical personnel. Members of the CHG team will coordinate this staffing plan to provide initial and continued staffing of delivery orders with skilled personnel. The significant elements of this approach include the following:

- Establishing lines of communications with other Site contractors to define staffing requirements clearly

- Identifying and codifying the skills, experience, and educational requirements for each position

- Identifying specific labor categories that may be difficult to fill and aggressively pursuing individuals who already meet the requirements or who can meet them with special training or assignments

- Determining the applicability of subcontracting to fulfill the needs, particularly when the need is of limited duration

- Maintaining strong relationships with local subcontractors and holding periodic briefing sessions outlining staffing needs so as to alert them of upcoming needs

- Maintaining a skills database containing names both internal and external applicants who meet Hanford Site requirements 


\section{RPP-6114 REV 0}

- Using corporate resources and internal newsletters to attract required talent from other CH2M HILL projects

- Using established CH2M HILL relationships with major universities in the Pacific Northwest to "track" top students into CHG through a combination of summer internships and direct recruiting

- Recruiting and advertising via the Internet

- Attending job fairs

- Reassessing staffing needs with FH and the Privatization Contractor quarterly.

This staffing plan addresses the periodic need to meet peak staffing requirements. In addition, CHG has contracts with temporary placement services to help supply highly trained personnel. CHG measures strategies and methods for efficiency and effectiveness by the following performance measures: cost per hire, offers per hire, applicants per hire, applicant acceptance rate, comparison analysis, compensation ratios, and effectiveness in time as it relates to days to hire. The general recruiting process for full-time staff is shown in Table 5-1.

Table 5-1. Recruitment Process.

\begin{tabular}{|c|c|}
\hline Define resource requirements. & $\begin{array}{l}\text { Identify resource requirements based on baseline } \\
\text { in P3. }\end{array}$ \\
\hline $\begin{array}{l}\text { Determine skills area gaps and develop } \\
\text { recruitment plan for those skill areas } \\
\text { with increases greater than the assumed } \\
\text { threshold. }\end{array}$ & $\begin{array}{l}\text { Compare resource requirements by COCS codes } \\
\text { to planned staffing levels. Develop recruitment } \\
\text { plans for COCS codes that have annual increases } \\
\text { over an estimated threshold. Tailor recruitment } \\
\text { plans for each COCS code and identify } \\
\text { recruitment approach, wage incentives, and } \\
\text { training requirements and costs. Update the } \\
\text { MYWP to cover recruitment and training costs. }\end{array}$ \\
\hline Implement recruitment strategy. & $\begin{array}{l}\text { HR implements recruitment plan for needed } \\
\text { resources and coordinates these efforts with the } \\
\text { appropriate project managers and other Hanford } \\
\text { Site contractor HR departments. }\end{array}$ \\
\hline \multicolumn{2}{|c|}{$\begin{array}{ll}\text { COCS } & =\text { Common Occupational Category System. } \\
\text { HR } & =\text { human resources. } \\
\text { MYWP } & =\text { multi-year work plan. } \\
\text { P3 } & =\text { Primavera Project Planner } \\
& \mathrm{TM} .\end{array}$} \\
\hline
\end{tabular}

The general recruiting process for construction project management, design and construction activities is shown in Table 5-2. 
Table 5-2. Construction/Subcontract Recruitment Process.

\begin{tabular}{|c|c|}
\hline $\begin{array}{l}\text { Develop contract specifications for the } \\
\text { design and construction phases of } \\
\text { construction projects. }\end{array}$ & $\begin{array}{l}\text { CHG will develop annual contract } \\
\text { projections for design (A/E) and construction } \\
\text { activities. This data will be incorporated into } \\
\text { MYWP planning activities. }\end{array}$ \\
\hline $\begin{array}{l}\text { Review staffing profiles for executability } \\
\text { by the planned work and subcontractor. }\end{array}$ & $\begin{array}{l}\text { Staff requirements will be optimized from an } \\
\text { execution standpoint, by FY, to ensure } \\
\text { project completion and optimum use of } \\
\text { personnel. }\end{array}$ \\
\hline Identify subcontractor labor requirements. & $\begin{array}{l}\text { Labor requirements are discussed with local } \\
\text { labor officials, A/E firms, and vendors to } \\
\text { determine availability of non-CHG } \\
\text { personnel. }\end{array}$ \\
\hline Subcontractors recruit required personnel. & $\begin{array}{l}\text { Unions, } \mathrm{A} / \mathrm{E} \text { firms, and vendors will recruit } \\
\text { labor from local union halls, professional } \\
\text { firms, and nationally as required. }\end{array}$ \\
\hline Provide required training to personnel. & $\begin{array}{l}\text { CHG will specify the training required to } \\
\text { qualify personnel to work on the assigned } \\
\text { activities. Training will be the responsibility } \\
\text { of the construction subcontractor who will } \\
\text { use the personnel. }\end{array}$ \\
\hline 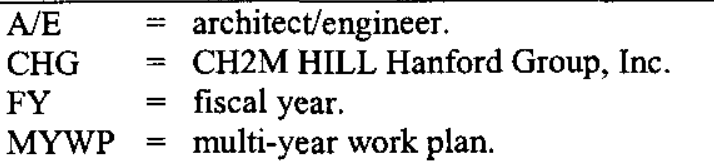 & \\
\hline
\end{tabular}

\subsection{TAILORED RECRUITMENT METHODS FOR IDENTIFIED SKILL AREAS}

\subsubsection{Crafts}

FY 2005 shows an increased need for craft workers in the baseline for the Privatization Contractor. The data are included in the staffing plan to highlight the need for these resources at the Hanford Site. However, the hiring and training of the individuals for these positions is not the contractual responsibility of CHG. CHG has requested that ORP resolve the issue of who is responsible for hiring and training the staff for these positions through the Integrated Process and Product Development/Interface Control Document process. When responsibility for hiring these workers is assigned, recruiting strategies can be developed. 


\subsubsection{Engineers}

A number of strategies will be used to recruit engineers. The primary methods of recruitment include advertising openings on the Internet; having established recruitment teams attend local job fairs; and establishing a rotational engineer program designed to attract new college graduates. CHG has established relationships with schools that identify engineering candidates who have climate and geographical preferences that are in keeping with the climate and geography of the Hanford Site area. CHG will attend national job fairs on an as-needed basis while maintaining an emphasis on local hiring. $\mathrm{CHG}$ also ensures its competitiveness by conducting and updating its compensation surveys. Other tools and strategies include the following:

- The completion of a skills area needs analysis, by engineering discipline, conducted by HR and the Chief Engineer's Office

- The establishment and maintenance of a resumé database categorized by skill mix and engineering discipline

- Initiation of an employee referral award program to provide incentives for CHG employees to refer engineering applicants

- Establishment of a transfer process within the CHG family of companies that provides incentives for engineers to transfer to $\mathrm{CHG}$ when their current assignments are completed

- Use of CHG employees as staff augmentation to address short-term spikes in staffing needs.

\subsubsection{Operators}

The major increase in FY 2005 staffing needs is for operators that are in the baseline for the Privatization Contractor. The data are included in the staffing plan to highlight the need for these resources at the Hanford Site. However, the hiring and training of the individuals for these positions is not the contractual responsibility of CHG. CHG has requested that ORP resolve the issue of who is responsible for hiring and training the staff for these positions through the Integrated Process and Product Development/Interface Control Document process. When responsibility for hiring these workers is assigned, recruiting strategies can be developed.

It is expected that the Privatization Contractor's need for nuclear operators can be met by the supply of out-placed operators from FH. Expectations are that the number of full-time staff needed by FH will be reduced by more than 114 in FY 2004, which will be enough to ensure that the Privatization Contractor's staffing demands can be met. 


\subsubsection{Health Physics Technicians}

A number of strategies will be used to recruit HPTs. The primary methods used by CHG will include recruitment near commercial and DOE nuclear facilities and via the Internet. If necessary, CHG can hire personnel and restart the HPT Technical Training Program at Columbia Basin College in Pasco, Washington, to train them. One strategy for the FY 2002 peak in demand is the use of temporary subcontractor HPTs. Because the work is under union jurisdiction, the effects will have to be negotiated between $\mathrm{CHG}$ and the International Brotherhood of Electrical Workers Local 984 and HAMTC. If necessary, CHG will team with $\mathrm{FH}$ to develop an integrated strategy for recruiting and hiring HPTs. 


\section{RPP-6114 REV 0}

This page intentionally left blank. 


\section{RPP-6114 REV 0}

\subsection{SUMMARY}

Based on this staffing plan, $\mathrm{CHG}$ is confident that it can recruit the staff required to execute Phase 1B of Privatization. Specific recruitment strategies are presented in detail in Sections 3.0 and 5.0 of this document. 


\section{RPP-6114 REV 0}

This page intentionally left blank. 


\subsection{REFERENCES}

Basche, A. D., 2000, Financial Analysis for Phase 1 Privatization for the Tank Farm Contractor, HNF-2017, Rev. 2, CH2M HILL Hanford Group, Inc., Richland, Washington.

CHG, 2000, Integrated Environment, Health, and Safety Management System Description for the Tank Farm Contractor, RPP-MP-003, Rev. 0, CH2M HILL Hanford Group, Inc., Richland, Washington.

CHG, 2000, RPP Administration, HNF-IP-0842, CH2M HILL Hanford Group, Inc., Richland, Washington.

- "Risk Management," Vol. IV, Section 2.6.

- "Health and Safety Program Description," Vol. IX, Section 1.1.

Diediker, J. A., 2000, Programmatic Baseline Summary for Phase I Privatization for the Tank Farm Contractor, HNF-1946, Rev. 2, CH2M HILL Hanford Group, Inc., Richland, Washington.

Ecology, EPA, and DOE, 1996, Hanford Federal Facility Agreement and Consent Order, 2 vols., Washington State Department of Ecology, Olympia, Washington;

U.S. Environmental Protection Agency, Washington, D.C.; and U.S. Department of Energy, Washington, D.C.

Halverson, T. G., 2000, Draft Project Execution Plan for the Tank Farm Contractor, RPP-6017, Rev. 0, CH2M HILL Hanford Group, Inc., Richland, Washington.

Harris, J. P. III, 2000, River Protection Project Double-Shell Tank Waste Retrieval Authorization Basis Amendment Task Plan, HNF-1722, Rev. 2, CH2M HILL Hanford Group, Inc., Richland, Washington.

Hebdon, J. B., 2000, Quality Assurance Program Description for the Tank Farm Contractor, RPP-MP-600, Rev. 0, CH2M HILL Hanford Group, Inc., Richland, Washington.

Honeyman, J. O., and J. A. Voogd, 2000, Memorandum of Readiness to Proceed with Phase 1 Privatization for the Tank Farm Contractor, RPP-6118, Rev. 0, CH2M HILL Hanford Group, Inc., Richland, Washington.

Kirkbride, R. A., 2000, Tank Farm Contractor Operation and Utilization Plan, HNF-SD-WM-SP-012, Rev. 2, CH2M HILL Hanford Group, Inc., Richland, Washington.

LMHC, 1999, River Protection Project FY 2000 Multi-Year Work Plan Summary, RPP-5044, Rev. 0, Lockheed Martin Hanford Corporation, Richland, Washington.

LMHC, 1999, Tank Farms Health and Safety Plan, HNF-SD-WM-HSP-002, Rev. 3B, Lockheed Martin Hanford Corporation, Richland, Washington. 
Mercado, L. C., 2000, Project Delivery Acquisition and Contracting Plan for the Tank Farm Contractor, RPP-6113, Rev. 0, CH2M HILL Hanford Group, Inc., Richland, Washington.

ORP, 2000, River Protection Project Mission Analysis Report, DOE/ORP-2000-10, Rev. 0, U.S. Department of Energy, Office of River Protection, Richland, Washington.

O'Toole, S. M., 2000, Systems Engineering Management Plan for the Tank Farm Contractor, HNF-SD-WM-SEMP-002, Rev. 2, CH2M HILL Hanford Group, Inc., Richland, Washington.

Powell, P.A., 2000, Environmental Program Description for the Tank Farm Contractor, HNF-1773, Rev. 3, CH2M HILL Hanford Group, Inc., Richland, Washington.

Rifaey, S. H., 1998, Tank Waste Remediation System Engineering Plan, HNF-1947, Rev. 0, Lockheed Martin Hanford Corporation for Fluor Daniel Hanford, Inc., Richland, Washington.

RL, 1996, Richland Environmental Restoration Project Management Action Process Document, DOE/RL 96-09, Rev. 1, U.S. Department of Energy, Richland Operations Office, Richland, Washington.

Schaus, P. S., 2000, River Protection Project Readiness-to-Proceed 2 Internal Independent Review Team Final Report, HNF-5835, Rev. 1, CH2M HILL Hanford Group, Inc., Richland, Washington.

Tedeschi, A. R., 2000, Technical Baseline Summary Description for the Tank Farm Contractor, HNF-1901, Rev. 2, CH2M HILL Hanford Group, Inc., Richland, Washington.

Weir, W. R., 2000, Configuration Management Plan for the Tank Farm Contractor, HNF-1900, Rev. 1, CH2M HILL Hanford Group Inc., Richland, Washington. 
RPP-6114 REV 0

ATTACHMENT A

CH2M HILL HANFORD GROUP, INC., NON-PROJECT STAFFING PROFILE SUMMARY 
RPP-6114 REV 0

This page intentionally left blank.

A-ii 
RPP-6114 REV 0

\section{ATTACHMENT A}

\section{CH2M HILL HANFORD GROUP, INC., NON-PROJECT} STAFFING PROFILE SUMMARY

\begin{tabular}{|c|c|c|c|c|c|c|c|c|c|c|}
\hline COSP & 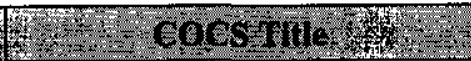 & 1700 & Prol: & 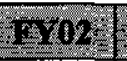 & Mis & mive & 1506 & 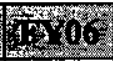 & 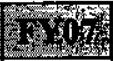 & 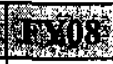 \\
\hline \multicolumn{11}{|c|}{ Crafts } \\
\hline $\mathrm{CO00}$ & Crafts & 8 & 9 & 7 & 7 & 8 & 112 & 7 & 9 & 41 \\
\hline $\mathrm{C} 010$ & Carpenters & 3 & 3. & 3 & 3 & 3 & 3 & 3 & 3 & 3 \\
\hline $\mathrm{C} 020$ & Electricians & 44 & 48 & 42 & 40 & 35 & 34 & 34 & 38 & 36 \\
\hline $\mathrm{C} 030$ & HVAC-heating/refrigeration & 0 & 0 & 0 & 0 & 0 & 0 & 0 & 0 & 0 \\
\hline $\mathrm{C} 040$ & Machinists & 8 & 4 & 4 & 1 & 3 & 1 & 4 & 6 & 1 \\
\hline $\mathrm{C} 060$ & Millwrights & 5 & 5 & 6 & 5 & 5 & 5 & 5 & 6 & 6 \\
\hline $\mathrm{C} 070$ & Painters & 4 & 4 & 5 & 5 & 5 & 5 & 5 & 5 & 5 \\
\hline $\mathrm{C} 080$ & Plumbers and pipefitters & 22 & 23 & 18 & 17 & 16 & 10 & 10 & 12 & 12 \\
\hline $\mathrm{C} 090$ & Structural and metal workers & 2 & 2 & 2 & 3 & 2 & 2 & 1 & 2 & 1 \\
\hline \multicolumn{11}{|c|}{ Engineers } \\
\hline $\mathrm{E} 000$ & Engineers & 47 & 36 & 45 & 44 & 33. & 29 & 28 & 43 & 54 \\
\hline E010 & Chemical engineers & 92 & 70 & 82 & 69 & 46 & 50 & 46 & 56 & 58 \\
\hline $\mathrm{E} 020$ & Civil engineers & 2 & 4 & 3. & 4 & 1 & 1 & 2 & 3 & 3 \\
\hline E040 & Electrical engineers & 35 & 33. & 31 & 32 & 27 & 22 & 24 & 25 & 25 \\
\hline $\mathrm{E} 050$ & Environmental engineers & 36. & 38 & 36 & 36 & 33 & 32 & 31 & 32 & 30 \\
\hline E060 & Industrial engineers & 2 & 2 & 2 & 2 & 2 & 2 & 2 & 2 & 2 \\
\hline $\mathrm{E} 070$ & Mechanical engineers & 44 & 41 & 46 & 29 & 29 & 22 & 18 & 20 & 18 \\
\hline $\mathrm{E} 080$ & Nuclear engineers & 13 & 10 & 12 & 12 & 12 & 12 & 13 & 14 & 15 \\
\hline $\mathrm{E} 090$ & Petroleum/mining engineers & 2 & 1. & 1 & 1 & 1 & 1 & 1 & 1 & 1 \\
\hline E100 & Plant engineers & 78 & 79 & 78 & 77 & 76 & 58 & 61 & 67 & 67 \\
\hline E110 & Quality control engineers & 29 & 30 & 29 & 27 & 26 & 22 & 21 & 26 & 34 \\
\hline $\mathrm{E} 120$ & Safety engineers & 42 & 48 & 41 & 44 & 40 & 44 & 35 & 37 & 37 \\
\hline \multirow[t]{2}{*}{ E130 } & Other engineers & 53 & 59 & 61 & 79 & 74 & 61 & 52 & 62 & 50 \\
\hline & General Administration & & & & & & & & & \\
\hline G000 & $\begin{array}{l}\text { General administration } \\
\text { secretarial, clerk }\end{array}$ & 2 & 0 & 0 & 2 & 0 & 0 & 0 & 0 & 11 \\
\hline G010 & Administrative assistants & 24 & 22 & 24 & 25 & 23 & 22 & 21 & 20 & 19 \\
\hline G020 & Office clerks (general) & 35 & 36 & 37 & 35 & 31 & 30 & 31 & 29 & 29 \\
\hline G030 & Office clerks (specialized) & 15 & 15 & 14 & 12 & 13 & 12 & 12 & 12 & 12 \\
\hline G030 & Office clerks (specialized) - BU & 0 & 0 & 0 & 0 & 0 & 0 & 0 & 0 & 0 \\
\hline G040 & Secretaries & 64 & 64 & 66 & 61 & 61 & 58 & 58 & 59 & 55 \\
\hline
\end{tabular}




\begin{tabular}{|c|c|c|c|c|c|c|c|c|c|c|}
\hline EOpes & Th & Solo & 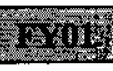 & 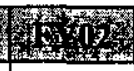 & 403 & 1. & 10 & 1100 & 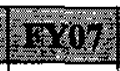 & +2008 \\
\hline & $\begin{array}{c}\text { Laborers and General Service } \\
\text { Workers }\end{array}$ & & & & & & & & & \\
\hline L000 & $\begin{array}{l}\text { Laborers and general service } \\
\text { workers }\end{array}$ & 4 & 3 & 2 & 3 & 3 & 2 & 2 & 2 & 2 \\
\hline L030 & Janitors and cleaners & 7 & 7 & 7 & 7 & 7 & 7 & 7 & 7 & 7 \\
\hline L070 & Light vehicle drivers & 4 & 5 & 4 & 4 & 4 & 4 & 4 & 3 & $\mathrm{f}$ \\
\hline & Managers & & & & & & & & & \\
\hline M000 & Managers & 3 & 2 & 2 & 2 & 2 & 2 & 2 & 2 & 19 \\
\hline M010 & First-line supervisors & 80 & 80 & 76 & 77 & 59 & 55 & 52 & 58 & 55 \\
\hline $\mathrm{M} 020$ & Managers and executives & 135 & 129 & 133 & 128 & 126 & 112 & 110 & 113 & 112 \\
\hline M030 & Project and program managers & 44 & 38 & 40 & 39 & 43 & 42 & 41 & 37 & 35 \\
\hline & Professional Administration & & & & & & & & & \\
\hline P000 & $\begin{array}{l}\text { Professional administration and } \\
\text { related occupants }\end{array}$ & 7 & 4 & 4 & 4 & 4 & 4 & 5 & 5 & 15 \\
\hline P010 & Accountants and auditors & 42 & 40 & 41 & 40 & 40 & 38 & 38 & 37 & 33 \\
\hline $\mathrm{P} 030$ & Buyers/procurement/contracting & 5 & 4 & 4 & 4 & 5 & 6 & 4 & 3 & 1 \\
\hline $\mathrm{P} 040$ & Communications specialists & 13 & 11 & 11 & 11 & 11 & 10 & 8 & 8 & 8 \\
\hline $\mathrm{P} 050$ & Compliance inspectors & 0 & 0 & 0 & 0 & 0 & 0 & 0 & 0 & 3 \\
\hline P060 & Computer systems analysts & 5 & 7 & 6 & 5 & 5 & 5 & 5 & 4 & 4 \\
\hline P070 & Planner/scheduler/estimators & 48 & 50 & 49 & 44 & 38 & 33 & 32 & 35 & 34 \\
\hline $\mathrm{P} 080$ & Health physicists & 21 & 21 & 27 & 23 & 18 & 19 & 20 & 20 & 21 \\
\hline $\mathrm{P} 090$ & Industrial hygienists & 6 & 4 & 4 & 4 & 4 & 5 & 4 & 4 & 5 \\
\hline $\mathrm{P} 110$ & Personnel and labor relations & 8 & 8 & 8 & 8 & 8 & 8 & 8 & 8 & 1 \\
\hline $\mathrm{P} 140$ & $\begin{array}{l}\text { Safeguards and security } \\
\text { specialists }\end{array}$ & 2 & 1 & 1 & 1. & 1 & 1 & 1 & 1 & 1 \\
\hline P150 & Trainers and instructors & 16 & 16 & 16 & 21 & 18 & 16 & 17 & 19 & 16 \\
\hline $\mathrm{P} 160$ & Technical writers and editors & 13 & 15 & 23 & 20 & 19 & 9 & 10 & 14 & 9 \\
\hline $\mathrm{P} 170$ & Other professionals & 9 & 9 & 9 & 9 & 9 & 8 & 8 & 8 & 8 \\
\hline & Operators & & & & & & & & & \\
\hline R000 & Operators & 8 & 3 & 3 & 4 & 2 & 110 & 5 & 13 & 34 \\
\hline $\mathrm{R} 030$ & $\begin{array}{l}\text { Material moving equipment } \\
\text { operator }\end{array}$ & 0 & 1 & 0 & 1 & 1 & 1 & 2 & 1 & 1 \\
\hline R040 & Nuclear plan operators & 1 & 0 & 0 & 0 & 0 & 0 & 0 & 0 & 0 \\
\hline R050 & Nuclear waste process operator & 226 & 221 & 228 & 212 & 135 & 172 & 110 & 123 & 138 \\
\hline $\mathrm{R} 070$ & Utilities system operators & 11 & 11 & 11 & 11 & 8 & 7 & 7 & 8 & 8 \\
\hline & Scientists & & & & & & & & & \\
\hline S000 & Scientists & 0 & 1 & 1 & 0 & 0 & 0 & 0 & 0 & 0 \\
\hline S010 & Chemists & 6 & 7 & 14 & 8 & 5 & 5 & 5 & 4 & 4 \\
\hline $\mathrm{S} 020$ & Environmental scientists & 6 & 6 & 5 & 5 & 5 & 5 & 5 & 5 & 5 \\
\hline $\mathrm{S} 030$ & Geologists/geophysicists/hydro & 2 & 1 & 1 & 1 & 1. & 1 & 1 & 0 & 0 \\
\hline $\mathrm{S} 050$ & Materials scientists & 1 & 1 & 1 & 1 & 1 & 1 & 1 & 1 & 1 \\
\hline
\end{tabular}




\section{RPP-6114 REV 0}

\begin{tabular}{|c|c|c|c|c|c|c|c|c|c|c|}
\hline $\mathrm{Cogs}$ & 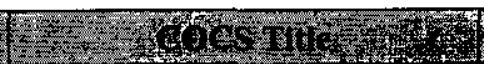 & 100 & $1 \times 10$ & 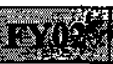 & (ns & 12 & 7. & 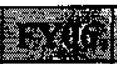 & 107 & 50 \\
\hline S060 & Mathematicians & 1 & 1 & 1 & 1 & 1 & 1 & 1 & 1 & 0 \\
\hline S070 & Physicists & 0 & 1 & 1 & 1 & 1 & 1 & 1 & 1 & 1 \\
\hline \multirow[t]{2}{*}{ S090 } & Other scientists & 1 & 1 & 2 & 2 & 2 & 2 & 2 & 1 & 1 \\
\hline & Technicians & & & & & & & & & \\
\hline $\mathrm{T} 000$ & Technicians & 2 & 0 & 0 & 0 & 0 & 0 & 0 & 1 & 10 \\
\hline T030 & Engineering technicians & 8 & 8 & 8 & 7 & 5 & 6 & 5 & 5 & 5 \\
\hline $\mathrm{T} 050$ & Health physics technicians & 125 & 146 & 171 & 130 & 131 & 90 & 82 & 87 & 111 \\
\hline T060 & $\begin{array}{l}\text { Industrial health/safety } \\
\text { technicians }\end{array}$ & 9 & 6 & 6 & 5 & 5 & 6 & 4 & 6 & 6 \\
\hline T070 & $\begin{array}{l}\text { Instrument and control } \\
\text { technicians }\end{array}$ & 36 & 37 & 36 & 38 & 34 & 36 & 38 & 40 & 44 \\
\hline T080 & Laboratory technicians & 3 & 3 & 4 & 4 & 4 & 4 & 4 & 4 & 4 \\
\hline $\mathrm{T} 110$ & Other technicians & 5 & 4 & 4 & 2 & 1 & 1 & 1 & 1 & 1 \\
\hline \multicolumn{2}{|c|}{ CHG staffing profile from $P 3$} & 1,634 & 1,599 & 1,660 & 1,559 & 1,371 & 1,485 & 1,177 & 1,282 & 1,405 \\
\hline \multicolumn{2}{|c|}{ Adjustment for operator bumping (R050) } & & & & & 31 & & & & \\
\hline \multicolumn{2}{|c|}{ CHG Staffing profile after adjustments } & 1,634 & 1,599 & 1,660 & 1,559 & 1,402 & 1,485 & 1,177 & 1,282 & 1,405 \\
\hline \multicolumn{2}{|c|}{ Subcontractor support - engineers } & 252 & 248 & 269 & 245 & 223 & 259 & 267 & 316 & 223 \\
\hline \multicolumn{2}{|c|}{$\begin{array}{l}\text { Subcontractor support - general } \\
\text { administration }\end{array}$} & 85 & 83 & 90 & 82 & 74 & 87 & 89 & 106 & 74 \\
\hline \multicolumn{2}{|c|}{ Subcontractor support - managers } & 15 & 15 & 15 & 15 & 15 & 15 & 15 & 15 & 15 \\
\hline \multicolumn{2}{|c|}{$\begin{array}{l}\text { Subcontractor support - professional } \\
\text { administration }\end{array}$} & 107 & 105 & 114 & 104 & 94 & 110 & 113 & 134 & 94 \\
\hline \multicolumn{2}{|c|}{ Subcontractor support - scientists } & 7 & 7 & 8 & 7 & 7 & 8 & 8 & 9 & 7 \\
\hline \multicolumn{2}{|c|}{ Subtotal subcontractor support } & 466 & 458 & 496 & 453 & 413 & 479 & 493 & 580 & 413 \\
\hline \multicolumn{2}{|c|}{$\begin{array}{l}\text { CHG staffing profile after } \\
\text { adjustments, including subcontractor } \\
\text { support }\end{array}$} & 2,100 & 2,057 & 2,156 & 2,012 & 1,815 & 1,964 & 1,670 & 1,862 & 1,818 \\
\hline
\end{tabular}

1. In FY 2005 P3 baseline incorrectly identified 54 engineers (E000) for turnover to the Privatization Contractor, instead of 54 operators (R050). Baseline data was adjusted to correct this error.

2. This staffing profile is based on a planned mix of $\mathrm{CHG}$ and subcontractor staff. As these positions are required, CHG will determine the appropriateness of subcontracting to fulfill the needs.

3. Estimated subcontractor support was based on the dollar value of contracts included in the CHG baseline.

$\mathrm{BU}=$ bargaining unit.

CHG $=$ CH2M HILL Hanford Group, Inc.

COCS $=$ Common Occupational Category System.

$\mathrm{FY}=$ fiscal year.

P3 = Primavera Project Planner ${ }^{\mathrm{TM}}$. 
RPP-6114 REV 0

This page intentionally left blank. 
RPP-6114 REV 0

ATTACHMENT B

STAFFING NEEDS FOR FEED DELIVERY/STORAGE CONSTRUCTION PROJECTS 
RPP-6114 REV 0

This page intentionally left blank.

B-ii 
RPP-6114 REV 0

\section{ATTACHMENT B}

\section{STAFFING NEEDS FOR FEED DELIVERY/STORAGE CONSTRUCTION PROJECTS}

\begin{tabular}{|c|c|c|c|c|c|c|c|c|c|c|}
\hline $\mathrm{Co} / \mathrm{s}$ & 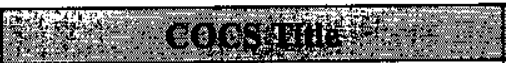 & 3.100 & Thor & 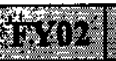 & $\operatorname{sing}$ & 2XYM & tons & Nog & SWly & xims \\
\hline & Crafts & & & & & & & & & \\
\hline $\mathrm{C} 010$ & Carpenters & 1 & 4 & 15 & 4 & 10 & 9 & 7 & 2 & 2 \\
\hline $\mathrm{CO} 20$ & Electricians & 1 & 19 & 70 & 33 & 44 & 37 & 28 & 15 & 10 \\
\hline $\mathrm{C} 030$ & HVAC-heating/refrigeration & 1 & 1 & 0 & 1 & 0 & 0 & 0 & 0 & 0 \\
\hline $\mathrm{C} 050$ & Masons & 0 & 0 & 1 & 1 & 1 & 1 & 1 & 1 & 1 \\
\hline $\mathrm{C} 060$ & Millwrights & 0 & 2 & 6 & 6 & 7 & 9 & 6 & 1 & 1 \\
\hline $\mathrm{C} 070$ & Painters & 1 & 4 & 8 & 3. & 8 & 5 & 3 & 1 & 1 \\
\hline $\mathrm{C} 080$ & Plumbers and pipefitters & 8 & 41 & 90 & 38 & 41 & 47 & 29 & 17 & 13 \\
\hline $\mathrm{C} 090$ & Structural and metal workers & 1 & 4 & 8 & 4 & 11 & 18 & 13 & 4 & 2 \\
\hline $\mathrm{C} 120$ & Other crafts & 0 & 10 & 25 & 18 & 20 & 25 & 20 & 15 & 13 \\
\hline $\mathrm{E} 000$ & Engineers & 1 & 1 & 2 & 4 & 4 & 4 & 2 & 1 & 1 \\
\hline E010 & Chemical engineers & 2 & 1 & 2 & 1 & 2 & 1 & 1 & 1 & 1 \\
\hline E020 & Civil engineers & 1 & 4 & 9 & 11 & 11 & 9 & 6 & 4 & 2 \\
\hline E040 & Electrical engineers & 4 & 7 & 15 & 27 & 21 & 14 & 9 & 5 & 2 \\
\hline E050 & Environmental engineers & 1 & 2 & 3 & 4 & 4 & 4 & 1 & 1 & 1 \\
\hline $\mathrm{E} 070$ & Mechanical engineers & 10 & 8 & 10 & 6 & 8 & 6 & 5 & 3 & 1 \\
\hline E080 & Nuclear engineers & 2 & 2 & 3 & 1 & 1 & 1 & 1 & 1 & 1 \\
\hline $\mathrm{E} 100$ & Plant engineers & 1 & 1 & 3 & 1 & 2 & $1)$ & 1 & 1 & 1 \\
\hline E110 & Quality control engineers & 2 & 5 & 7 & 4 & 4 & 4 & 1 & 1 & 1 \\
\hline $\mathrm{E} 120$ & Safety engineers & 1 & 8 & 12 & 8 & 8 & 8 & 5 & 2 & 2 \\
\hline E130 & Other engineers & 15 & 28 & 49 & 71 & 59 & 42 & 35 & 25 & 18 \\
\hline E140 & Construction engineers & 1 & 8 & 11 & 7 & 8 & 7 & 4 & 2 & 2 \\
\hline G000 & $\begin{array}{l}\text { General administration secretarial, } \\
\text { clerk }\end{array}$ & 1 & 1 & 1 & 1 & 1 & 1 & 1 & 1 & 1 \\
\hline G010 & Administrative assistants & 1 & 1 & 1 & 1 & 1 . & 1 & 1 & 1 & 1 \\
\hline $\mathrm{G} 020$ & Office clerks (general) & 2 & 1 & 3 & 1 & 2 & 2 & 1 & 1 & 1 \\
\hline G040 & Secretaries & 2 & 15 & 27 & 19 & 20 & 16 & 8 & 4 & 2 \\
\hline L000 & $\begin{array}{l}\text { Laborers and general service } \\
\text { workers }\end{array}$ & 6 & 31 & 107 & 51 & 67 & 67 & 49 & 35 & 30 \\
\hline M000 & Managers & 10 & 22 & 23 & 22 & 20 & 15 & 10 & 5 & 3 \\
\hline M010 & First line supervisors & 2 & 9 & 7 & 1 & 1 & 1 & 1 & 1 & 1 \\
\hline M020 & Managers and executives & 4 & 3 & 5 & 4 & 3 & 2 & 2 & 2 & 2 \\
\hline $\mathrm{M} 030$ & Project and program managers & 6 & 5 & 6 & 6 & 6 & 5 & 3 & 2 & 2 \\
\hline P010 & Accountants and auditors & 2 & 8 & 13 & 10 & 9 & 8 & 4 & 2 & 2 \\
\hline $\mathrm{P} 020$ & Architects & 0 & 1 & 1 & 6 & 5 & 4 & 1 & 1 & 1 \\
\hline P030 & Buyers/procurement/contracting & 2 & 5 & 7 & 5 & 6 & 6 & 3. & 1 & 1 \\
\hline
\end{tabular}




\section{RPP-6114 REV 0}

\begin{tabular}{|c|c|c|c|c|c|c|c|c|c|c|}
\hline Tho & 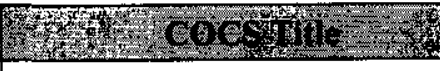 & 5 & 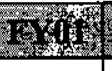 & mixion & 10 & ing & Plos & 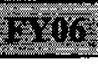 & 180 & Bing \\
\hline P050 & Compliance inspectors & 0 & 1 & 1 & 1 & 1 & 1 & 1 & 1 & 1 \\
\hline P070 & Planner/scheduler/estimators & 3 & 5 & 6 & 4 & 4 & 2 & 2 & 1 & 1 \\
\hline P080 & Health physicists & 1 & 2 & 19 & 6 & 20 & 3 & 2 & 2 & 2 \\
\hline P090 & Industrial hygienists & 0 & 0 & 0 & 0 & 0 & 0 & 0 & 0 & \\
\hline P150 & Trainers and instructors & 0 & 1 & 2 & 3 & 2 & 2 & 1 & 1 & 1 \\
\hline P160 & Technical writers and editors & 1 & 7 & 17 & 14 & 10 & 8 & 2 & 1 & 1 \\
\hline P170 & Other professionals & 1 & 요 & 1 & 1 & 1 . & 1. & 1 & 1 & 1 \\
\hline R000 & Operators & 0 & 10 & 17 & 12 & 11 & 11 & 7 & 5 & 5 \\
\hline \multicolumn{2}{|c|}{ Total Equivalent Staff } & 98 & 288 & 613 & 421 & 464 & 408 & 278 & 171 & 135 \\
\hline
\end{tabular}

COCS = Common Occupational Category System.

$\mathrm{FY}=$ fiscal year.

HVAC $=$ heating, ventilation, and air conditioning. 
RPP-6114 REV 0

\section{DISTRIBUTION}

\section{Onsite}

U.S. Department of Energy

Richland Operations Office

DOE Public Reading Room

$\mathrm{H} 2-53$

1

Pacific Northwest National Laboratory

Hanford Technical Library

P8-55

2

Lockheed Martin Services, Inc.

Central Files

B1-07

Document Processing Center

A3-94

Distr.-1 
RPP-6114 REV 0

This page intentionally left blank.

Distr.-2 